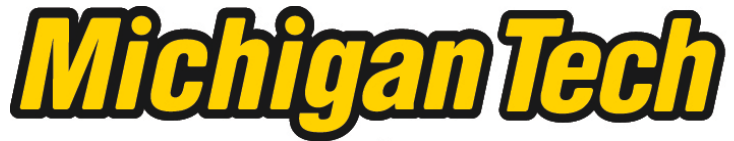 \\ Michigan Technological University Create the Future Digital Commons @ Michigan Tech
}

2012

\section{Nitrogen Deposition Effects on Production and Decomposition of Coarse Woody Debris}

Bethany Jeanne Lyons

Michigan Technological University

Follow this and additional works at: https://digitalcommons.mtu.edu/etds

Part of the Ecology and Evolutionary Biology Commons, and the Forest Sciences Commons Copyright 2012 Bethany Jeanne Lyons

\section{Recommended Citation}

Lyons, Bethany Jeanne, "Nitrogen Deposition Effects on Production and Decomposition of Coarse Woody Debris", Master's Thesis, Michigan Technological University, 2012.

https://doi.org/10.37099/mtu.dc.etds/467

Follow this and additional works at: https://digitalcommons.mtu.edu/etds

Part of the Ecology and Evolutionary Biology Commons, and the Forest Sciences Commons 


\title{
NITROGEN DEPOSITION EFFECTS ON PRODUCTION AND DECOMPOSITION OF COARSE WOODY DEBRIS
}

By

Bethany J. Lyons

\begin{abstract}
A THESIS
Submitted in partial fulfillment of the requirements for the degree of

MASTER OF SCIENCE

In Forest Ecology and Management
\end{abstract}

MICHIGAN TECHNOLOGICAL UNIVERSITY

2012

(C) 2012 Bethany J. Lyons 
This thesis has been approved in partial fulfillment of the requirements for the Degree of MASTER OF SCIENCE in Forest Ecology and Management.

School of Forest Resources and Environmental Science

Thesis Advisor: $\quad$ Dr. Andrew Burton

Committee Member: $\quad$ Dr. Linda Nagel

Committee Member: $\quad$ Dr. Paul Doskey

Committee Member: $\quad$ Dr. Janice Glime

School Dean: $\quad$ Dr. Terry Sharik 


\section{Table of Contents}

\section{NITROGEN DEPOSITION EFFECTS ON PRODUCTION AND DECOMPOSITION}

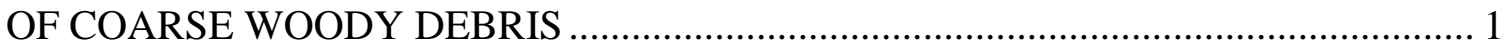

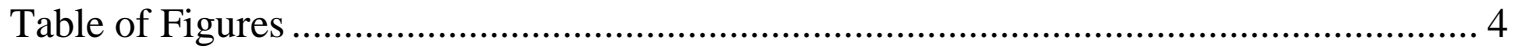

Table of Tables …............................................................................................. 5

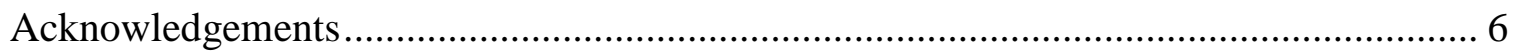

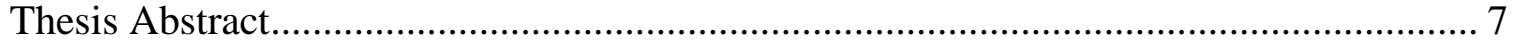

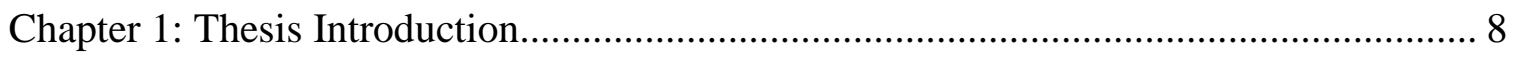

Chapter 2: Chronic Simulated Nitrogen Deposition and the Decomposition of Coarse

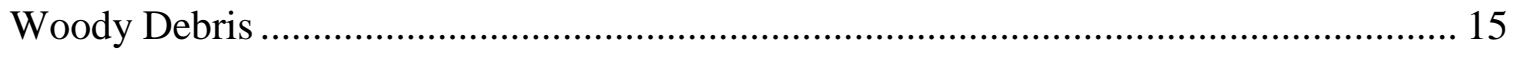

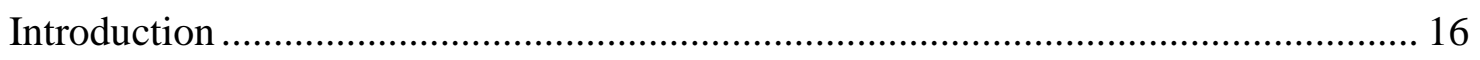

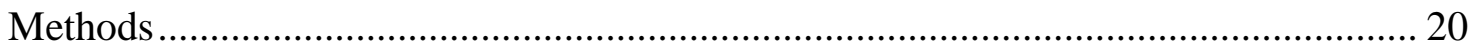

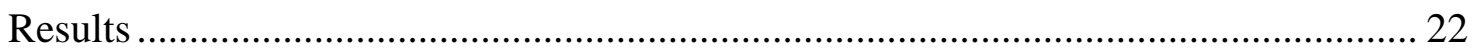

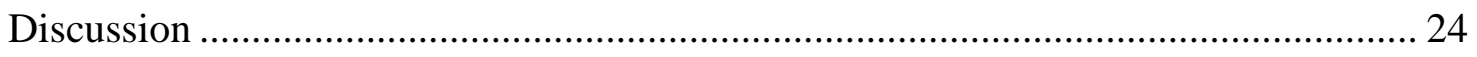

Chapter 3: An Assessment of Coarse Woody Debris Biomass and Forest Stand Dynamics under Chronic Simulated Nitrogen Deposition.......................................................... 36

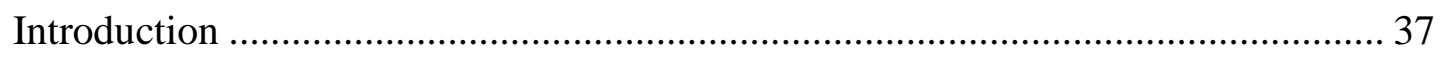

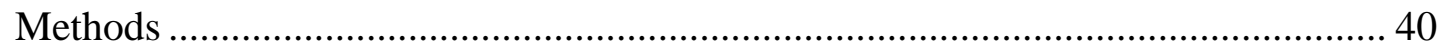

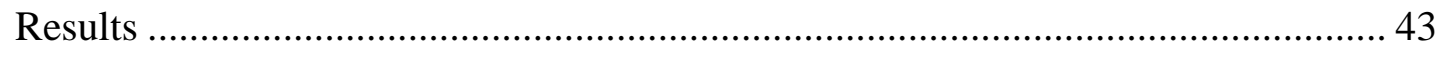

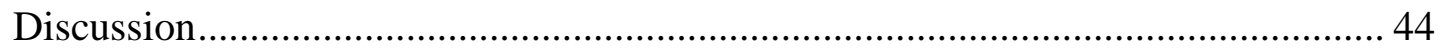

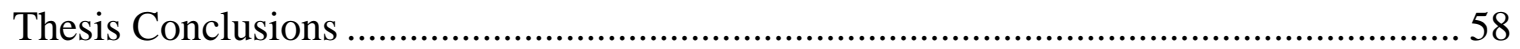

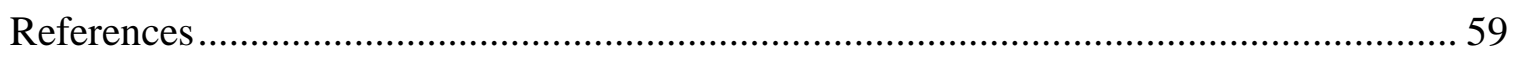




\section{List of Figures}

\section{Chapter 2}

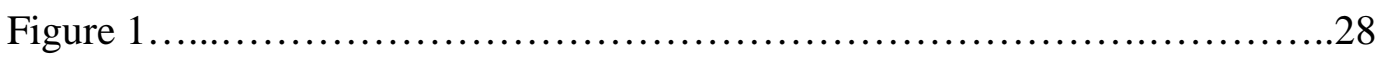

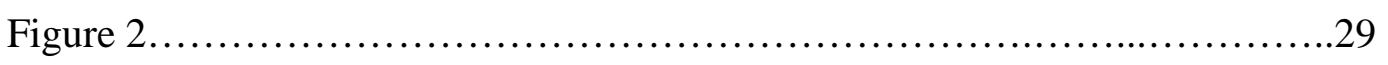

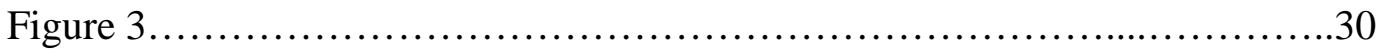

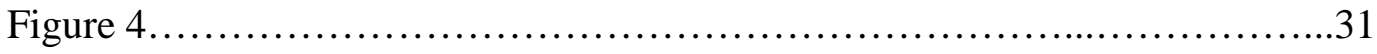

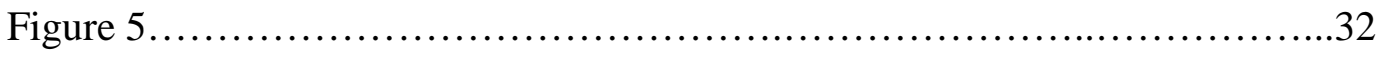

\section{Chapter 3}

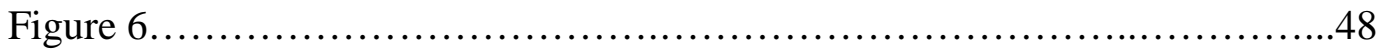

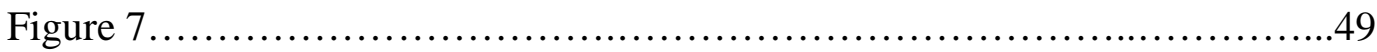

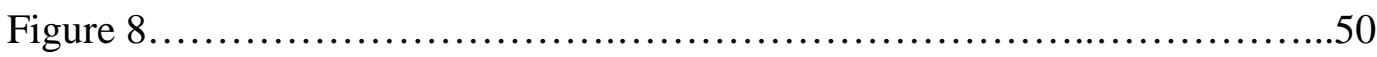

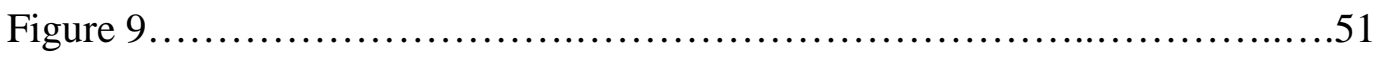

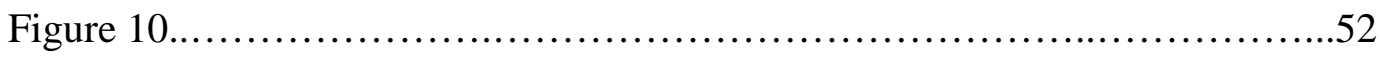

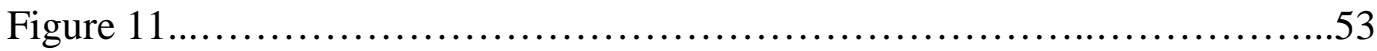




\section{List of Tables}

\section{Chapter 2}

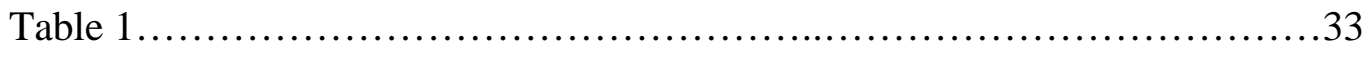

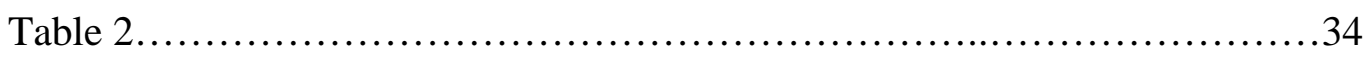

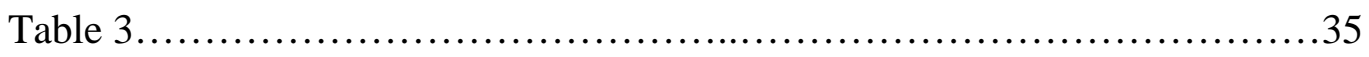

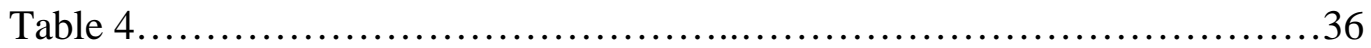

\section{Chapter 3}

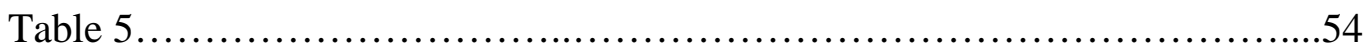

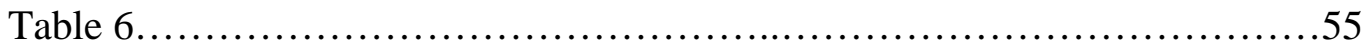

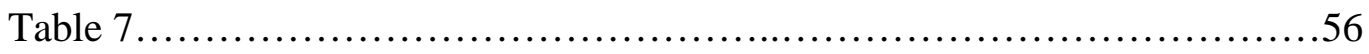

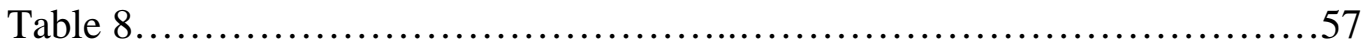

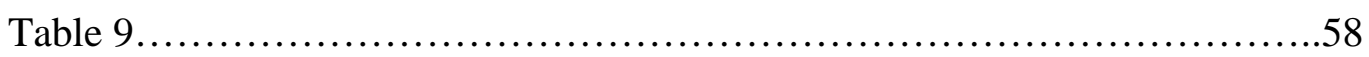




\section{Acknowledgements}

The following thesis could not have been accomplished without the guidance and support from a number of people. I would like to thank Dr. Andrew Burton for his supervision of my Master of Science program and for his advice and assistance in all academic and research related issues. Not only has he helped me with graduate school and research, he has also been kind, light-hearted, and understanding throughout my time as his advisee. I look forward to working with him more in the future as a PhD student and into my career.

I would like to thank my committee members: Dr. Linda Nagel, Dr. Paul Doskey, and Dr. Janice Glime. Their guidance and support is much appreciated. They represent a diverse set of backgrounds and specialties. I hope I can gain a fraction of that knowledge as I move on through research and academia. Unfortunately, this MS was a fast-track program and so I have not had a chance to get to know my committee members very well. I hope that I get that opportunity in the next few years at Michigan Tech and into my career.

I would also like to thank the people of the Burton lab. I'd like to thank Jennifer Eikenberry. She has always been patient and kind with me. She was integral in the elemental analysis of my wood samples. I wanted to thank her for putting up with my chatty nature, my absent-mindedness, and my poor driving skills. A certain member of the Burton Lab is also deserving of thanks. I would like to thank Mickey Jarvi. He has helped me with statistical analysis, formatting issues, thesis and general school advice. I could not have begun as a TA without his example before me. Being one of the first people I met at Michigan Tech, Mickey gave me the best impression of a school, a lab, and a colleague. I will always consider him a good friend as well. There are several other Burton Lab members and friends deserving of thanks including, Kayla Griffith and Jerry Jondreau. Our shared experiences have molded my world view and have strengthened my confidence as a student and as a person. I appreciate all of them immensely. 


\section{Thesis Abstract}

Atmospheric nitrogen deposition has the potential to impact forest productivity, microbial associations, nutrient cycling, decomposition and stand dynamics. However, among the least studied aspects of these processes are the production and decomposition of dead woody biomass, or coarse woody debris (CWD). Coarse woody debris is made up of dead woody material on the ground called down dead wood (DDW) and dead standing trees which are often referred to as snags. Observed reductions in decomposition of CWD have been linked to substrate quality and microbial communities. If the decomposition effect is ubiquitous among litter types, CWD density, C:N, and biomass are likely to be impacted by elevated $\mathrm{N}$ deposition. Previous research found a slight increase in mortality in the $\mathrm{N}$-amended plots. By assessing CWD volume and biomass, we can conjecture the potential impacts of N-deposition on stand dynamics. This study analyzes the influence of chronic simulated N-deposition on the decomposition of CWD along a latitudinal gradient in Michigan. Methodology included assessing DDW volume and biomass from ambient and elevated $\mathrm{N}$ deposition treatments, classifying downed dead wood and snags by their respective visual qualitative decay classes, and calculating wood density and $\mathrm{C}: \mathrm{N}$ ratios.

Since N deposition treatments began in 1994, DDW biomass has accrued by $16 \%$ in $\mathrm{N}$ amended plots. Wood density and C: $\mathrm{N}$ ratios were significantly and negatively correlated with years since tree death in ambient (control) treatment plots $(\mathrm{P}=0.003$ and 0.005 respectively). $\mathrm{N}$ amended wood density and $\mathrm{C}: \mathrm{N}$ ratios did not significantly decline over times since tree death. Analysis of covariance, with years since tree death as a covariate, indicated that $\mathrm{N}$ deposition treatment caused an increase in average DDW density and $\mathrm{C}: \mathrm{N}$ ratio ( $\mathrm{P}=0.063$ and 0.060 respectively). Our analysis indicates that $\mathrm{N}$ deposition has the potential to slow rates of wood decomposition and therefore the accumulation of dead woody biomass over time.

\section{Key words: $\mathbf{N}$ deposition, decomposition, coarse woody debris, downed dead wood, lignin}




\section{Chapter 1: Thesis Introduction}

\section{Nitrogen deposition}

Atmospheric nitrogen $(\mathrm{N})$ deposition is a natural process that continuously delivers atmospheric $\mathrm{N}$ compounds to terrestrial and aquatic ecosystems via precipitation and dry particle deposition. During the process of fossil fuel combustion, nitrogen oxides $\left(\mathrm{NO}_{\mathrm{x}}\right)$ are produced that are deposited on surrounding regions in the form of aerosol nitrate $\left(\mathrm{NO}_{3}{ }^{-}\right)$and ammonium $\left(\mathrm{NH}_{4}{ }^{+}\right)$(Barnes et al. 1998). To support the demand for food, N-containing fertilizers must be applied to agricultural soils to maximize productivity. Excess $\mathrm{N}$ can occur from over-fertilization; this $\mathrm{N}$ is then cycled through aquatic and terrestrial ecosystems and can have significant effects on ecosystem functioning and biological processes. As the human population continues to grow, the rate of $\mathrm{N}$ addition is expected to increase as well. Scientists expect a $25 \%$ increase in N deposition for developed countries in the coming decades (Galloway et al. 1994). Asia alone contributes roughly $27 \%$ of global $\mathrm{NO}_{\mathrm{x}}$ emissions and $43 \%$ of ammonia emissions (Galloway et al. 2008).

North America is expected to receive an extra $3 \mathrm{~g} \mathrm{NO}_{3} \mathrm{~m}^{-2} \mathrm{yr}^{-1}$ for northern temperate forests (Galloway 2004). Nitrogen is thought to be the most important and often the most limiting nutrient for terrestrial ecosystems (Brady and Weil, 2008). Increases in available nitrogen can have broad implications for a number of forest processes, including productivity (Aber et al. 1995), decomposition (Johannes et al. 2007), and subsequent carbon storage (Barford et al. 2001). In N limited terrestrial ecosystems, experimental $\mathrm{N}$ additions can rapidly create $\mathrm{N}$ saturated conditions, where leaching nearly equals additions (Aber et al. 1989; Fenn et al. 1998; Zak et al. 2004). High $\mathrm{N}$ treatments have also been found to cause soil acidification; up to $70 \%$ reduction of base exchangeable cations (Högberg et al. 2006). Both increases in N mineralization and N mobilization have been observed under simulated N deposition (Magill et al. 1997; Garten 1999). 


\section{Forest response to $N$ deposition}

Globally there is an unidentified carbon sink that sequesters $15-30 \%$ of the world's carbon (C) emissions (Myneni et al. 2001). Several recent articles have speculated that northern temperate forests could represent a percentage of this unaccounted C sink (White et al. 2000; Myneni et al. 2001; Burton et al. 2004;Zak et al. 2008; Pregitzer et al. 2008) although other studies have debated this (Currie et al. 2004; Hogberg, 2007;). Magnani et al. (2007) speculates that “mankind is ultimately controlling the carbon balance in temperate and boreal forests directly through forest management and indirectly through $\mathrm{N}$ deposition.” Because of the potential of a significant $\mathrm{C}$ sink within temperate forests, it is important to understand the mechanisms behind $\mathrm{C}$ storage in forests. A meta-analysis of forest inventory data along a natural $\mathrm{N}$ deposition gradient in the United States reported that aboveground woody biomass increased by $61 \mathrm{~kg}$ of $\mathrm{C}$ per kg of $\mathrm{N}$ deposited, accompanied by increased tree growth in species with mycorrhizal associations (Thomas et al. 2009). In a long-term simulated N deposition experiment, Pregitzer (2008) noted an increase in woody biomass production (live + dead woody biomass pools) over a decade of $\mathrm{N}$ additions. However, other studies have correlated $\mathrm{N}$ additions to decreased tree growth and vigor (Thomas et al. 2009), increased mortality (Shen et al. 2000), as well as reduced seedling survival (Patterson et al. 2012; Catovsky et al. 2010). Thus it appears that future levels of $\mathrm{N}$ deposition may accelerate stand dynamics by influencing competitive interactions at the individual and species level.

Several studies have described a positive correlation between $\mathrm{N}$ deposition and productivity (Nave et al. 2009; Pregitzer et al. 2008). Nave et al. (2009) reported that up to $15 \%$ of net primary productivity (NPP) in northern hardwoods is a result of atmospheric $\mathrm{N}$ inputs. Increased NPP due to $\mathrm{N}$ deposition can result from reduced $\mathrm{C}$ allocation to mycorrhizae (van Diepen et al. 2007) and elevated foliar N. When $\mathrm{N}$ becomes more available under elevated $\mathrm{N}$ deposition conditions, plants and trees may shift $\mathrm{C}$ allocation away from $\mathrm{N}$ seeking mycorrhizal associations. Although $\mathrm{N}$ deposition can increase productivity, captured NPP must remain sequestered on site (not lost through mortality and decomposition) in order to have an impact on the degree of $\mathrm{C}$ 
stored. The primary process that returns soil carbon from a "storage" state to the atmosphere is through heterotrophic respiration- the central process within decomposition.

\section{Decomposition}

Decomposition is the process by which organic matter is broken down into successively smaller components and metabolized by heterotrophs to produce energy and biomass. The process of decomposition releases $\mathrm{CO}_{2}$ through heterotrophic respiration. Recent long term $\mathrm{N}$ deposition studies have found a significant "slowing" in the process of litter decomposition. Some studies have observed this result indirectly through reduced soil respiration (Burton et al., 2004; Cusack et al., 2010;) and heterotrophic respiration (Janssens et al., 2010), while others have found correlations with litter quality (Berg and Meetemeyer, 2002; Mansson and Falkengren-Grerup, 2003) enzyme activity (Carreiro et al., 2000; DeForest et al., 2004; Waldrop et al., 2004; Sinsabaugh, 2010; Wang et al., 2010), microbial genetic analyses (Blackwood et al., 2007; Hofmockel et al., 2007; Hassett et al., 2009;), and microbial biomass (Zeglin 2007; Treseder, 2008;). The explanation for reduced decomposition due to elevated $\mathrm{N}$ additions has been linked to (I) the substrate being decomposed and (II) the community of decomposers.

\section{Substrate}

It has long been known that litter quality is an important factor in determining rates of decomposition (Meetenmeyer 1978). Most decomposition studies are done in leaf litter and soil organic matter mediums. Litter substrates include sugars and starches (simple carbohydrates), hemicellulose and cellulose, and lignin-like (recalcitrant) molecules (Brady and Weil 2008). Within the succession of decomposition, simple carbohydrates are easily attainable and often utilized quickly by microbial decomposers. Cellulose is a polysaccharide chain made up of repeating glucose molecules held by 
covalent (glycosidic) bonds. Hemicellose (a matrix of cellulose chains) is harder to break down compared to simple carbohydrates but is still considered relatively labile (Horwath 2007). Lignin is made up of repeated phenyl-propane units with several types of bonding. It is the primary structural macromolecule within plant cell walls (Horwath 2007). The term "lignin" can be misleading as it was (and often still is) used to define a "waste group” of highly recalcitrant molecules, that were either formed because of harsh chemical washes or were the bulky macromolecules left over after several chemical extractions (Schmidt et al. 2011). True lignin has been renamed "acid unhydrolyzable residue," or "Klason lignin.” For the purposes of this thesis we will use 'lignin' for simplicity. Excessive soil $\mathrm{N}$ has been found to modify the structure of the lignin molecule, accentuating its recalcitrance (Berg and Matzner 1997). Low molecular weight $\mathrm{N}$ containing compounds are adsorbed into lignin's covalent bonds essentially enhancing lignin's resistance to decomposition (Stevenson 1982). Many researchers have observed that under elevated $\mathrm{N}$ deposition the decomposition of cellulose and hemicellulose components was accelerated, while the decomposition of lignin-like (recalcitrant) components was reduced (Berg and Matzner 1997; Li et al. 1994; Johannes et al. 2007; Carreiro et al. 2000; Waldrop and Zak 2006; Wang et al. 2010; Sinsabaugh 2010, DeForest et al. 2004; Cusack et al. 2010). Researchers have attributed an elevated N effect on microbial decomposer communities and function to this broadening gap between the decomposition of labile and recalcitrant molecules.

\section{Decomposer community}

Within forests, bacteria and fungi mediate the process of decomposition (Barnes et al. 1998). Certain fungal groups occupy specific niche spaces determined by their preferred substrate. The range of tolerance of a substrate also varies by species. For example, lignin decomposition often occurs during the final stages of litter decay and is mediated by a specialized group of lignin degraders called white-rot fungi (basidiomycetes) (Campell, 1930; Hammel, 1997; Osono, 2007). Several articles have speculated that microbial community shifts could at least partially explain the stimulation 
and inhibition of enzyme activities under elevated soil N (Hofmockel et al. 2007; Treseder 2008; Weand et al. 2010; van Diepen et al. 2007; Lucas and Casper 2008; Waldrop et al. 2004; Zak et al. 2011). Much of this research has yielded varying results that cannot be compared across sites based on differing methodologies (time, forest type, specific microbial community, and analysis). Methodological issues include whether the authors used microbial biomass, phospholipid fatty-acid analysis, or genetic testing as a means of estimating changes in microbial community composition. When it appeared that lignin-degrading basidiomycete activity was low due to $\mathrm{N}$ inputs, Zak et al. (2011) hypothesized that basidiomycete competitors like lignin-degrading Actinobacteria, would fill in an apparently open niche space and decomposition activity (production of enzymes) would resume. Their results showed otherwise; elevated $\mathrm{N}$ inputs did not significantly alter competitive interactions among soil bacteria and fungi. Determining microbial community shifts poses a problem because several different microbial species carry out similar functions with similar enzymes (Osono 2007). With more research using transcriptomic analyses, researchers will not only be able to identify microbial species abundance but they will also be able to separate microbial abundance/biomass from genetic activity (i.e. function).

\section{Microbial function}

Microbial decomposers produce enzymes that can oxidize specific macromolecular substrates to obtain $\mathrm{C}$ and other nutrients for growth and respiration (Thorn and Lynch 2007). Excess $\mathrm{N}\left(\mathrm{NO}_{3}{ }^{-}\right.$and $\left.\mathrm{NH}_{4}{ }^{+}\right)$is thought to interfere with the fungal metabolism of lignin, thus inhibiting decomposition (Sinsabaugh et al., 2002; Frey et al., 2004). On the other hand, other microbial decomposers specialized on cellulosebased compounds seem to receive a beneficial boost in activity (Berg and Matzner, 1997). Under elevated $\mathrm{N}$ deposition, cellulase activity increased, illustrating the accelerated decomposition associated with more labile $\mathrm{C}$ macromolecules. Laccase (phenol oxidase) activity decreased with high levels of soil N. Some research has considered that excess $\mathrm{N}$ has a direct effect on fungal metabolism (Hofmockel 2007), 
however, the effect of $\mathrm{N}$ deposition on laccase was found at the genetic level as well (Blackwood et al. 2007; Lauber et al. 2009). Nearly all literature published on N deposition and decomposition focuses on leaf litter, soil organic matter, or culture experiments, which can have varying concentrations of labile and recalcitrant substances.

\section{Michigan Gradient Study}

This study follows research from a Long Term Research in Environmental Biology (LTREB) project that has been simulating chronic elevated $\mathrm{N}$ deposition along a latitudinal gradient in Michigan. An additional $3 \mathrm{~g} \mathrm{NO}_{3}{ }^{-} \mathrm{m}^{-2} \mathrm{y}^{-1}$ has been broadcasted every growing season on treatment plots since 1994. Researchers noted that leaf biomass, root biomass, and root turnover remained constant (Burton et al. 2004), but surface soil organic matter $\left(0-10 \mathrm{~cm}\right.$ ) increased (690 $\mathrm{g} \mathrm{C} \mathrm{m}^{-2}$ ) (Pregitzer et al. 2008) under elevated $\mathrm{N}$ deposition. This indicates that $\mathrm{N}$ deposition did not increase soil organic matter by producing more leaf or root biomass but by slowing the decomposition of organic matter. Zak et al. (2008) reported that after a decade of experimental $\mathrm{N}$ deposition, organic matter increased (12\%) in the forest floor and surface mineral soil layers. Soil respiration has decreased (Burton et al. 2004) as has sugar maple (Acer saccharum Marsh.) seedling survival (Patterson et al. 2012). These findings indicate that elevated $\mathrm{N}$ deposition has altered the process of decomposition and potentially influenced stand dynamics at the Michigan Gradient sites.

To our knowledge, there is little known about the effect of $\mathrm{N}$ deposition on CWD decomposition. Large pieces of CWD have long residence times and play an important role in carbon and nitrogen storage and cycling (Creed et al. 2004; Ganjegunte et al. 2004). To determine if the $\mathrm{N}$ deposition treatment has altered decomposition rates, I analyzed CWD wood densities and C:N ratios for CWD produced by tree death during the project (see Chapter 2). I also assessed the effects of chronic $\mathrm{N}$ addition on CWD biomass and volume, as well as the differences due to site, decay class, and time. Chapter 3 contains biomass and volume analysis and a discussion on stand dynamics. 
The objectives of this study were to determine if CWD decomposition was altered under elevated $\mathrm{N}$ deposition, to discuss the possible accumulation of DDW volume and biomass under elevated $\mathrm{N}$ deposition, and to promote the inclusion of CWD in carbon storage predictions under future levels of $\mathrm{N}$ deposition. I hypothesized that $\mathrm{N}$ additions would reduce CWD decomposition due to an inhibition of white-rot fungi and that enhanced tree growth due to $\mathrm{N}$ addition would accelerate stand dynamics, increasing tree mortality through stem exclusion (i.e. increasing the production of CWD). I also hypothesized that reduced decomposition and accelerated stand dynamics would foster greater C storage in CWD under elevated $\mathrm{N}$ deposition. 
Chapter 2: Chronic Simulated Nitrogen Deposition and the Decomposition of Coarse Woody Debris 


\section{Introduction}

Due to anthropogenic activities, ecosystems around the world are currently experiencing increasing levels of inorganic atmospheric nitrogen $(\mathrm{N})$ deposition (Detener et al. 2006). To meet the world's demand for energy and food, the combustion of fossil fuels and the excessive use of fertilizer have significantly influenced the global cycling of nitrogen. Research suggests a 25\% increase in total N deposition by the year 2020 for developed countries like North America (Galloway et al. 1994). Within North America, this increase translates to an extra $3 \mathrm{~g} \mathrm{NO}_{3}{ }^{-}$and $\mathrm{NH}_{3} \mathrm{~m}^{-2} \mathrm{yr}^{-1}$ for northern hardwood forests (Galloway et al. 2004).

In temperate forest ecosystems, $\mathrm{N}$ is considered one of the most limiting factors for forest productivity (Brady and Weil 2008). Not only is it needed by plants to build amino acids (proteins, enzymes, and genetic material) and is an integral element of chlorophyll, soil bacteria and fungi also actively seek N-containing compounds for their own growth and metabolism (Thorn and Lynch 2007). Because of this dependence on N, forest communities and the processes that maintain them can be significantly altered by rising levels of $\mathrm{N}$ deposition (Magill et al. 1997; Myneni et al. 2001; Magnani et al. 2007).

Increased experimental $\mathrm{N}$ deposition has been found to influence a suite of forest processes including net primary productivity (NPP) (Nave et al. 2009; Pregitzer et al. 2008), soil respiration (Burton et al., 2004; Cusack et al., 2010; Janssens et al., 2010), microbial enzyme activities (Waldrop et al., 2004; Carreiro et al., 2000; Wang et al., 2010; Sinsabaugh, 2010; DeForest et al., 2004), and leaf litter decomposition (Johannes et al. 2007; Prescott 1995). Research on the effects of elevated $\mathrm{N}$ on microbial and fungal decomposers has had varying results (Knorr 2005). Excess $\mathrm{N}$ availability has been found to increase the activity of some microbial and fungal decomposers; in contrast, other research has documented a marked decline in decomposition under elevated soil $\mathrm{N}$. Based on a review of the literature it appears these conflicting accounts are a result of two 
factors: the substrates being decomposed, and the makeup of the microbial "decomposer" community.

Nitrogen mediated declines in the decomposition of lignin have been attributed to an elevated $\mathrm{N}$ response in specialized soil fungi that degrade lignin: basidiomycetes (Boominathan et al. 1990). These specialized fungi produce enzymes including phenol oxidase, manganese peroxidase, and lignin peroxidase (only found in wood-degraders) that can breakdown the bulky lignin molecule and obtain the cellulose hidden within the lignin shell (Osono 2007). A group of bleaching fungi known as "white rot" basidiomycetes are, "the most abundant degraders of wood in nature" and the primary wood degraders in hardwood systems (Hammel 1997).

A culture study done on a nutrient deregulated lignin-degrader found that the nitrogen deregulated mutant Phanerochaete chrysosporium, a white rot basidiomycete, produced four-fold the amount of lignin peroxidase compared to that produced by wild types in a low $\mathrm{N}$ medium. In contrast, wild types produced no detectable amount of lignin peroxidase in high $\mathrm{N}$ media while the $\mathrm{N}$ deregulated mutants continued to produce excess peroxidase enzymes (Boominathan et al. 1990). Carreiro et al. (2000) demonstrated that elevated $\mathrm{N}$ deposition increased the activity of microbial and fungal cellulases but decreased the activity of laccaces (phenol oxidase). Other research has documented the same decrease in phenol oxidase activity due to $\mathrm{N}$ additions (Berg and Matzner 1996; Li et al. 1994; Johannes et al. 2007; Carreiro et al. 2000; Waldrop and Zak 2006; Wang et al. 2010; Sinsabaugh 2010, DeForest et al. 2004; Cusack et al. 2010). The inhibition of enzymatic activity at high-N concentrations is present across several forest types (Gallo et al. 2004). These findings and several other publications confirm that elevated $\mathrm{N}$ specifically reduces the decomposition of the macromolecule lignin through the inhibition of specialized lignin-degrading enzymes.

The unique lignin-specific response to elevated $\mathrm{N}$ inputs has been explained in a number of ways. The most comprehensive mechansim states that elevated $\mathrm{N}$ conditions uncouple the decomposition of polysaccharides (i.e. cellulose) and polyphenols (i.e. lignin). At the genetic level, $\mathrm{N}$ regulates the transcription of lignin degrading enzymes, 
where low $\mathrm{N}$ stimulates the production of lignin-degrading enzymes. There also is evidence that excess $\mathrm{N}$ affects decomposition through shifts in the decomposer community (Frey et al. 2005; DeForest et al. 2004; Waldrop et al. 2003; Zak et al. 2011). DeForest et al. (2004) observed a 35\% decrease in phenol oxidase activity and an $18 \%$ reduction in microbial biomass with $\mathrm{N}$ addition in northern hardwood forests, relative to a control treatment. Waldrop et al. (2003) demonstrated the widening gap in substrate decomposition by finding a greater microbial response to maple litter and a reduced response to oak litter, where oak litter had relatively larger concentrations of recalcitrant, lignin-like molecules. These findings illustrate that reductions in enzymatic activity may not be entirely responsible for the reduction in decomposition. Elevated $\mathrm{N}$ deposition appears to affect each component of decomposition: substrate, microbial community, and microbial function (Sinsabaugh et al. 2002; Knorr et al. 2005).

Interestingly, nearly all decomposition studies, either short term $\mathrm{N}$ fertilization studies or chronic elevated $\mathrm{N}$ deposition studies, utilized leaf litter as the substrate. Leaf litter is composed of several types of macromolecules which vary in concentration based on tree species and environmental conditions (Weedon et al. 2009). These macromolecules include water-soluble substances like simple carbohydrates, holocellulose, glycoproteins, hydrophobic lipids and waxes, and acid unhydrolyzable residues (lignin) (Brady and Weil 2008). Lignin concentration in leaf litter varies widely among species (Melillo 1982; Meetenmeyer 1978), but wood litter or coarse woody debris (CWD) is more consistent, containing approximately 25\% lignin (this can vary somewhat between gymnosperms and angiosperms) (Sjostrom 1993). Weedon et al. (2009) states the necessity for more research on wood traits that affect CWD decomposition patterns including $\mathrm{N}$ and $\mathrm{P}$ content as well as $\mathrm{C}: \mathrm{N}$ ratios. Based on a review of the literature there have not been any elevated $\mathrm{N}$ deposition studies that assessed wood decomposition. 


\section{Objective and hypotheses}

The objective of this study was to determine whether the inhibitory effect of elevated $\mathrm{N}$ availability on the decomposition of plant litter is ubiquitous in coarse woody debris. We determined the degree of decomposition by assessing wood density $\left(\mathrm{g} \mathrm{cm}^{-3}\right)$ and C:N ratios in CWD produced over a seventeen year period in northern temperate forests receiving ambient and experimentally elevated $\left(+3 \mathrm{~g} \mathrm{~N} \mathrm{~m}^{-2} \mathrm{y}^{-1}\right) \mathrm{N}$ deposition. We hypothesized (1) that chronic elevated $\mathrm{N}$ deposition inhibits the decomposition of CWD, and (2) that this inhibition is reflected in higher wood density and higher wood carbon to nitrogen $(\mathrm{C}: \mathrm{N})$ ratios. 


\section{Methods}

\section{Site description}

The four study sites used in this research are located across a $500 \mathrm{~km}$ latitudinal gradient in Michigan (Figure 1). All four sites contain three $30 \mathrm{~m}$ x $30 \mathrm{~m}$ treatment plots and three $30 \mathrm{~m}$ x $30 \mathrm{~m}$ control plots. Since 1994, elevated N-deposition has been simulated by broadcasting $0.5 \mathrm{~g} \mathrm{~N} \mathrm{~m}^{-2}$ month ${ }^{-1}$ of solid $\mathrm{NaNO}_{3}$ pellets in 6 equal applications during the growing season $\left(3 \mathrm{~g} \mathrm{~N} \mathrm{~m}^{-2}\right.$ annually). The sites receive total ambient $\mathrm{N}$ deposition ranging from 0.7 to $1.2 \mathrm{~g} \mathrm{~N} \mathrm{~m}^{-2} \mathrm{yr}^{-1}$ (Table 1). All sites contain similar flora, being primarily composed of Acer saccharum (80\% of basal area) with Acer rubrum, Quercus rubra, Fagas grandifolia, and Prunus serotina components (Table 1). The four sites are representative of northern hardwood forests (see Burton et al. 1991 for further information on site characteristics) with Kalkaska sand (Typic haploorthod) soils, similar age, and similar stand structure.

\section{Coarse Woody Debris Density and C:N}

All trees within each plot have been numbered, with diameter at breast height (dbh) measured annually at permanent marks since 1987 for ambient plots and since 1994 for $\mathrm{N}$ amended plots. Tree death has been recorded during annual measurements. Every tree within the study plots has known coordinates which allows them to be easily located. Wood from every third downed dead tree dying between 1994 and 2011 on all plots was sampled during the summer of 2011. Decay classes 1 through 5 were used to classify down dead wood (DDW), or trees that died and are now lying on the forest floor, while decay classes 11, 22, and 33 were used to classify dead standing trees (snags). Decay class 1 indicated the tree was freshly fallen and often still had fine branches and possibly leaves. Decay class 2 was separated from decay class 3 by the presence of bark and secondary branches. Decay class 4 appeared slightly ellipsoidal with some fragmentation as well as evidence of insect and fungal attack. Decay class 5 was highly fragmented, 
often sunken in soil and moss covered. Decay classes 11, 22, and 33 are the same as decay classes 1, 2, and 3 except that they were applied to dead trees that were still standing (snags). The use of different codes for snags aided in identifying and tracking samples in the laboratory. Each decay class is a relative measurement of decomposition for debris pieces (methods adapted from Duvall and Grigal 1999).

Wood sampling was done using either a chainsaw for decay classes 1-3 (sometimes 4), or steel core (5 cm diameter) for decay classes 4 and 5. A hole-saw or chisel was used to collect wood samples from every third dead standing tree. Sample volume was calculated manually with dimension measurements from steel core samples and by water displacement on a balance (for unbroken wood) for all other samples. Samples were then placed in a drying oven at $65{ }^{\circ} \mathrm{C}$ until a constant mass was achieved. Wood density $\left(\mathrm{g} \mathrm{cm}^{-3}\right)$ was obtained from volume and dry mass measurements. The samples then were prepped for $\mathrm{C}$ and $\mathrm{N}$ analysis by grinding in a Spex CertiPrep ball mill to a fine powder. All samples were analyzed for C and N using a Fisons NA 1500 elemental analyzer.

\section{Statistical analysis}

Analysis of Variance (ANOVA), with site and treatment as factors was used to assess treatment effects on wood density. Decay class was not used as a factor due to the limited number of wood samples from each decay class, especially decay class 5 . Analysis of covariance (ANCOVA), with years since death as a covariate, was also used. Linear regression models were used to compare changes over time in wood density for the ambient and $\mathrm{N}$ amended plots, with years since death as a predictor. Wood C:N ratios were tested for effects of $\mathrm{N}$ deposition treatment with analysis of covariance (ANCOVA) with site and treatment as factors and years since death as a covariate. The relationship between $\mathrm{C}: \mathrm{N}$ ratios and time was tested with a linear regression model, with years since death being the predictor variable for the $\mathrm{C}: \mathrm{N}$ ratio response. 


\section{Results}

\section{Wood density}

In ambient plots, wood density decreased with higher decay classes. In $\mathrm{N}$ amended plots, wood density remained higher relative to ambient plots, throughout all decay classes (Figure 2). There was no detectable trend in snag wood density. Dead standing wood density fluctuated with visual decay classes (Figure 2). Because of the variability in snag wood density for snag decay classes, we assessed wood density in relation to years since tree death.

A two-way ANOVA revealed that site and $\mathrm{N}$ addition treatment affected wood density (Table 2). However, with years since death added as a covariate in an ANCOVA the effect of $\mathrm{N}$ addition treatment on wood density was reduced (Table 3). Years since death made a difference in ANCOVA results, i.e. higher density in more recently dead woody material. In other words, older CWD in N-amended plots had lost less mass than the older CWD in ambient plots. With a linear regression model, wood density in ambient plots significantly decreased with years since death (Figure 4): density $=0.610-0.0256 \mathrm{x}$ years since death $(\mathrm{r}=-.530, \mathrm{P}=0.003)$. However, wood density in the $\mathrm{N}$ amended treatment did not exhibit a similar relationship. In fact, the relationship between wood density and years since death in $\mathrm{N}$ amended plots was non-significant $(\mathrm{r}=-0.010, \mathrm{P}=$ 0.562; Figure 4).

\section{Wood C:N ratios}

Results for the C:N ratios were analogous to those for wood density. ANCOVA results indicated that wood $\mathrm{C}: \mathrm{N}$ ratio was significantly affected by site and $\mathrm{N}$ addition treatment with years since death as a covariate (Table 4). Like wood density, linear regression analysis indicated the decrease with time since death in wood C:N ratios was significantly greater for ambient than for $\mathrm{N}$-amended plots (Figure 5). For ambient plots 
wood C: $\mathrm{N}$ ratio $=368.232-11.866 \mathrm{x}$ years since death $(\mathrm{r}=0.34, \mathrm{P}=0.005)$. $\mathrm{N}$-amended plots did not have a significant linear relationship between $\mathrm{C}: \mathrm{N}$ ratio and years since death $(r=0.153, P=0.226)$. 


\section{Discussion}

Our findings support the hypothesis that chronic elevated $\mathrm{N}$ deposition suppressed the decomposition of CWD and this effect was seen reduced rates of mass loss over time and higher wood $\mathrm{C}: \mathrm{N}$ ratios for the experimental $\mathrm{N}$ deposition treatment along $\mathrm{a}$ latitudinal gradient in Michigan’s northern hardwood forests.

\section{Wood density}

Site had a significant effect on wood density because of a much higher average wood density at site A $\left(0.50 \mathrm{~g} \mathrm{~cm}^{-3}\right)$ versus sites $\mathrm{B}, \mathrm{C}$, and D (from $0.29-0.31 \mathrm{~g} \mathrm{~cm}^{-3}$ ). The site difference could be attributed to species or environmental factors at site A which causes higher wood density and higher subsequent C:N ratios. Site A has the lowest mean annual temperature (Table 1). Cooler conditions at site A could contribute to lower overall decomposition rates as well as reduced live tree growth. Site A also has the highest percentage of sugar maple, which has higher wood density than the other major species on the study sites. Across decay class 2, site A had the highest average wood density therefore, CWD decomposition at site A starts with a higher wood density.

Within the plots that received ambient $\mathrm{N}$ deposition, wood density decreased with time (Figure 2). As decomposition proceeds, soil microbes and fungi break covalent bonds between polymers and wood becomes aerated, light, and highly fragmented. Plots receiving chronic experimental additions of $\mathrm{NO}_{3}{ }^{-}$did not exhibit this trend. In the later stages of decay (classes 3 and 4 in Figure 1 and years 8-17 in Figure 2), wood from the $\mathrm{N}$ deposition plots exhibited higher densities than ambient plots. This indicates that overall, older pieces of coarse woody debris are less dense in ambient plots; in other words older CWD in $\mathrm{N}$ amended plots is less decomposed than in ambient plots. 


\section{Wood C: $N$ ratios}

Differences in wood C:N ratios were similarly explained by the effects of site, treatment, and years since death (Table 2). Wood C:N ratios exhibited practically the same response as wood density. Wood C:N ratios in ambient plots displayed a significant negative linear response to years since death (Figure 3). In contrast, the relationship between wood C:N ratios and years since death from $\mathrm{N}$ amended plots was nonsignificant (Figure 3). As wood C:N decreases in ambient plots, either $\mathrm{N}$ is being imported via the life cycles of microbial decomposers, e.g. dead fungal hyphae releasing $\mathrm{N}$ into the decaying wood, or $\mathrm{C}$ is being lost via respiration. In $\mathrm{N}$ amended plots, excess soil $\mathrm{N}$ did not influence $\mathrm{C}: \mathrm{N}$ ratios as they remained relatively high in new CWD (Figure 3). The wood density and wood C:N data sets are independent Errors in wood volume measurements could have affected wood density estimates. However wood volume errors would not have altered $\mathrm{C}: \mathrm{N}$ results.

\section{Decomposition effect: substrate, enzymes, and carbon storage}

The effects of elevated $\mathrm{N}$ deposition on decomposition are two-fold: it increases the production of cellulases i.e. it accelerates the decomposition of more labile substrates and it reduces the production of phenol oxidases and peroxidases, i.e, it slows the decomposition of lignin (Waldrop et al. 2004; Carreiro et al. 2000; Wang et al. 2010; Sinsabaugh, 2010; DeForest et al. 2004). The decomposition of lignin is a naturally slow process (Osono 2007; Horwath 2007). This “widening” of the gap between decomposition of labile and recalcitrant macromolecules has led researchers to question the ability of forest ecosystems under elevated $\mathrm{N}$ deposition to sequester soil carbon (Myneni et al. 2000; White et al. 2000). The addition of $\mathrm{N}$ to leaf litter has been found to “lead to greater accumulations of humified organic matter" (Prescott 2010). Several studies have observed decreases in soil respiration (Burton et al., 2004; Cusack et al., 2010), some even specifically heterotrophic respiration (Janssens et al. 2010). Taken together, N deposition increases carbon fixation (increased NPP); decreases C lost 
(decreased soil/heterotrophic respiration, and increases the amount of $\mathrm{C}$ retained (reduced decomposition/humification of organic matter) (Saiya-cork et al. 2002; Pregitzer et al. 2008; Berg and Matzner 1997). In sum, we can surmise that future levels of $N$ deposition will have the potential to increase carbon storage in northern hardwood forests and that future forest C storage models must consider the role of accumulating C in CWD, due in part to reduced decomposition.

In a recent finding from the same Michigan Gradient study, Thomas et al. (2012) concluded that although organic matter has accumulated under chronic simulated $\mathrm{N}$ deposition and extracellular enzyme activity is correlated with treatment, the relative oxidation state of lignin was not related to the activity of lignin-degrading enzymes. Instead, "microbial transformations of root detritus may underlie the accumulation of organic matter." Therefore the authors concluded that within the $\mathrm{N}$ amended forest floor and mineral soil layers, lignin-like molecules were not accumulating and that the biochemical composition of soil organic matter was not correlated with extracellular enzyme activity.

Because we found direct evidence of reduced decomposition of CWD (density and $\mathrm{C}: \mathrm{N}$ ), the effect of $\mathrm{N}$ deposition on decomposition appears to be ubiquitous among litter types (leaf litter, soil organic matter, and CWD). In contrast with the conclusions of Thomas et al. (2012), accumulations of CWD are clearly not root-derived. Because C:N is correlated with the concentration of lignin-like molecules (Weedon et al. 2009), C does in fact appear to be accumulating, at least within CWD. Therefore the relationship between fungal communities, extracellular enzyme activity, relative oxidation of lignin, and substrate composition, all under the effect of elevated $\mathrm{N}$ deposition, requires further understanding and refinement. It may be the case that several different mechanisms underlie the response of decomposition to $\mathrm{N}$ deposition, which might include substrate variability and changes in microbial community composition. If several mechanisms do underlie this response, then the most striking finding is that all mechanisms seem to lead to an accumulation of organic matter and therefore an accumulation of C. 


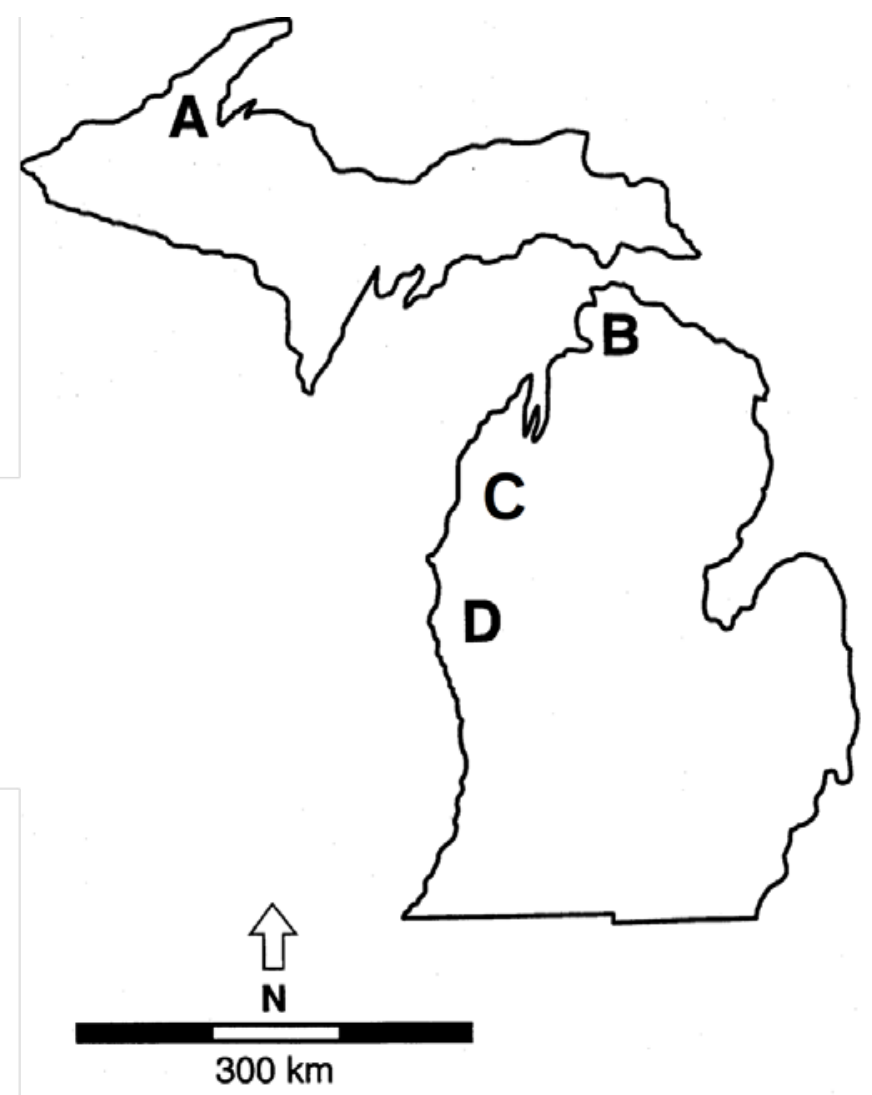

Figure 1. Four replicate sites along a north-south climatic gradient in Michigan have been receiving chronic elevated $\mathrm{N}$ additions since 1994. $\mathrm{N}$ amendments are in the form of solid $\mathrm{NaNO}_{3}$ pellets, applied in 6 equal increments during the growing season ( $3 \mathrm{~g} \mathrm{~N} \mathrm{~m}^{-2}$ annually). 


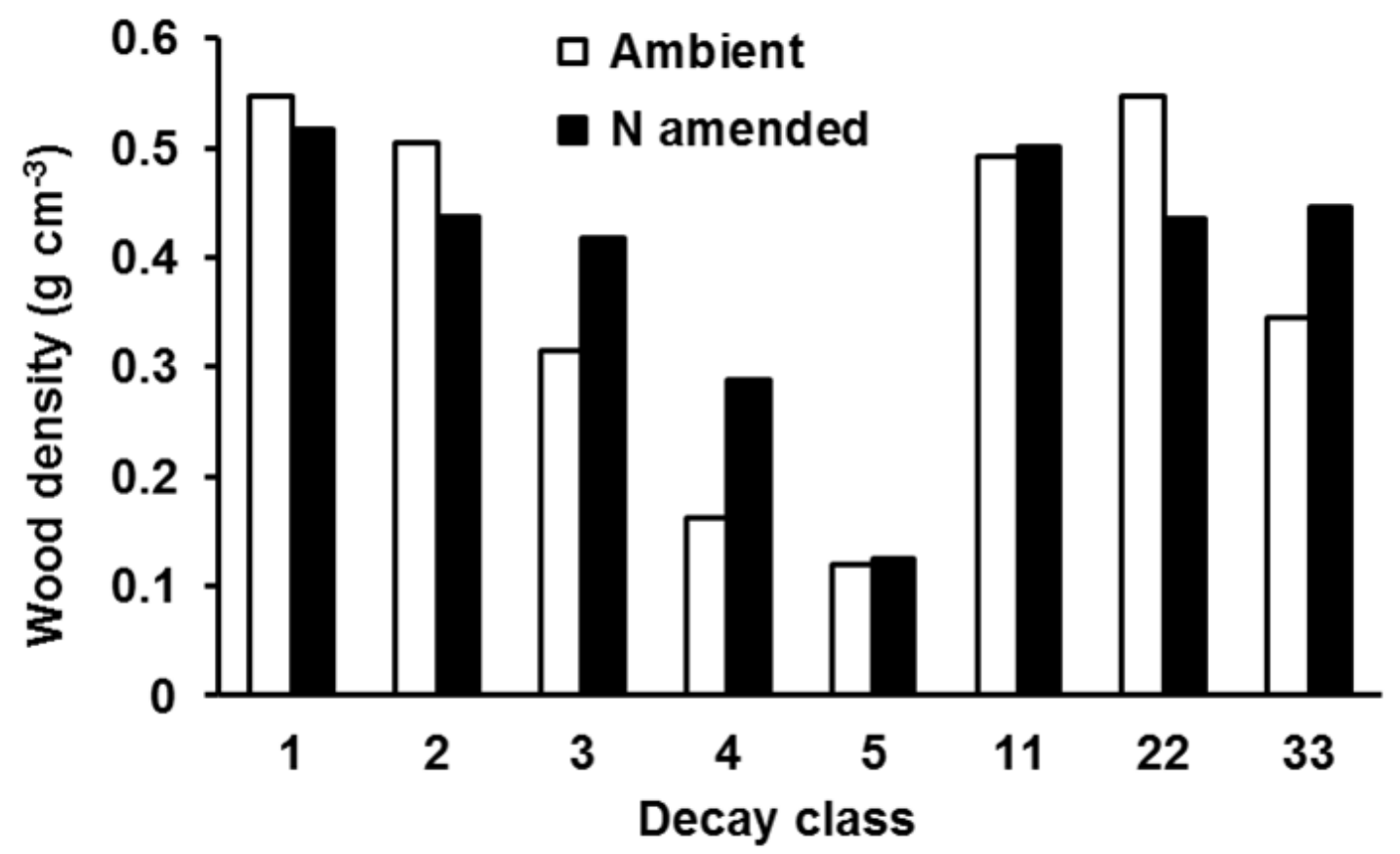

Figure 2. CWD density for visual decay classes in ambient and $\mathrm{N}$ amended treatments 


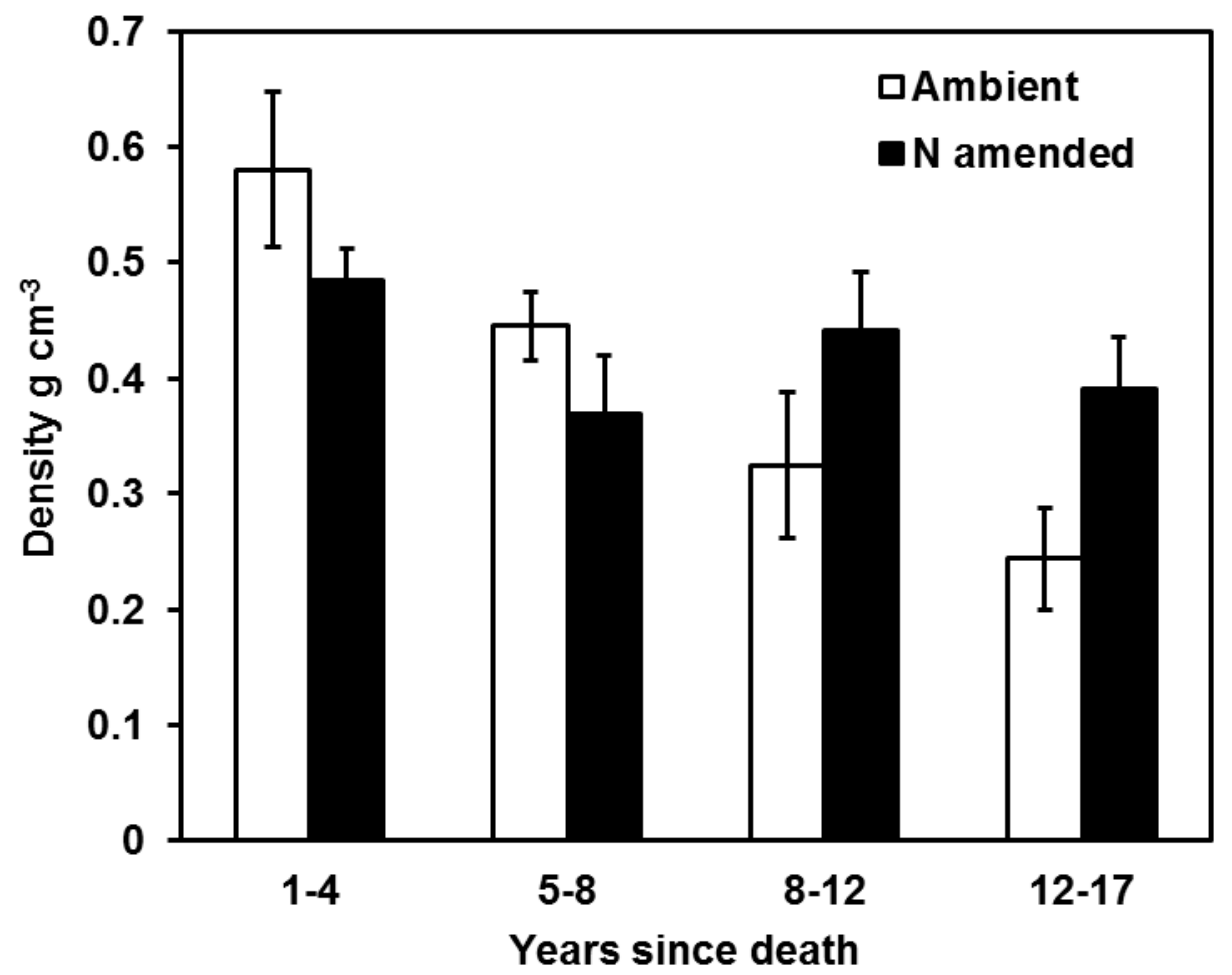

Figure 3. Wood density for the ambient and $\mathrm{N}$ amended treatments by years since death classes. Error bars indicate \pm 1 standard error of the mean within each treatment for years since death classes. 


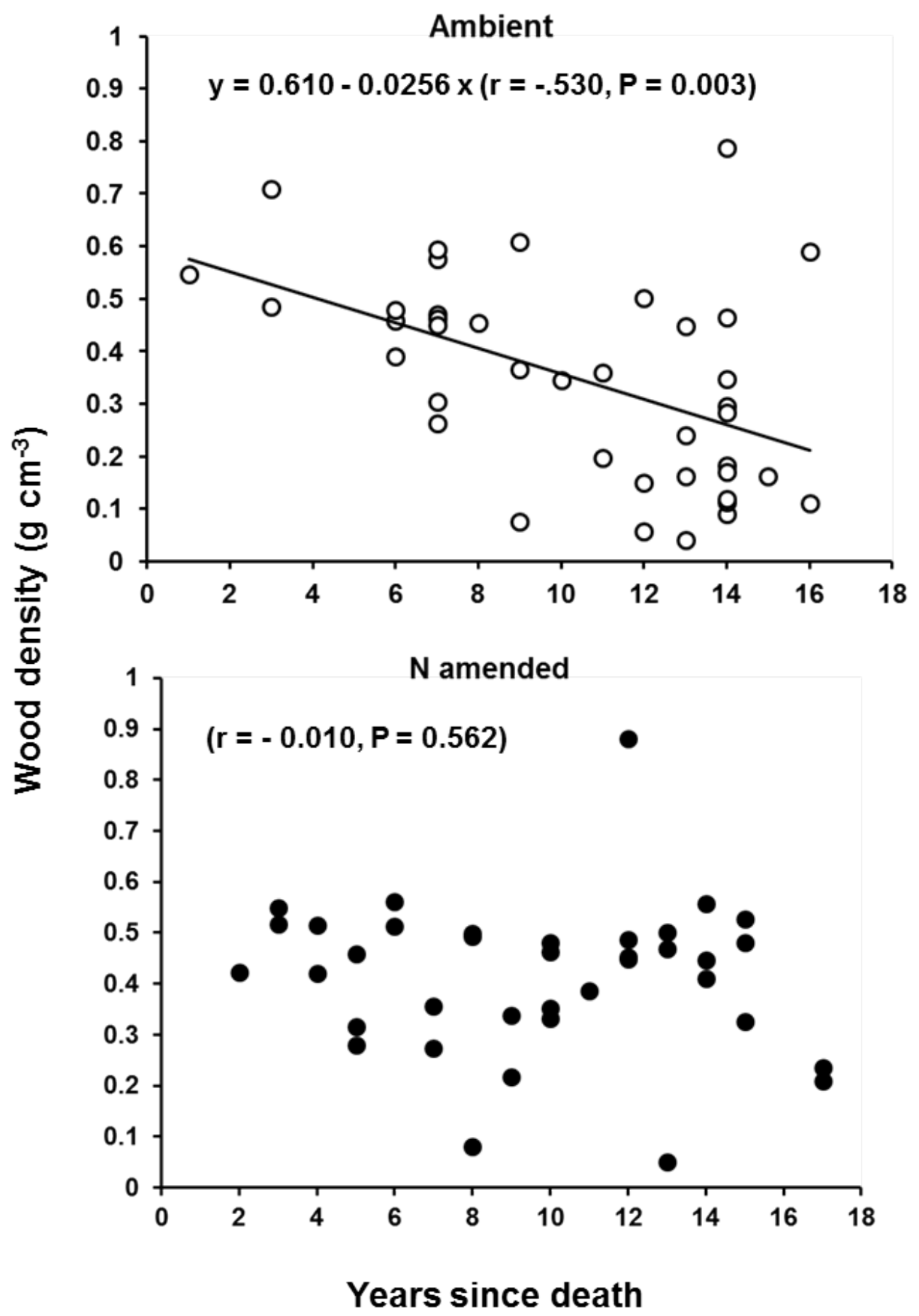

Figure 4. Scatter plot of CWD density by years since tree death for ambient and $\mathrm{N}$ amended treatments. Data is from wood sampling in 2011 field season. 


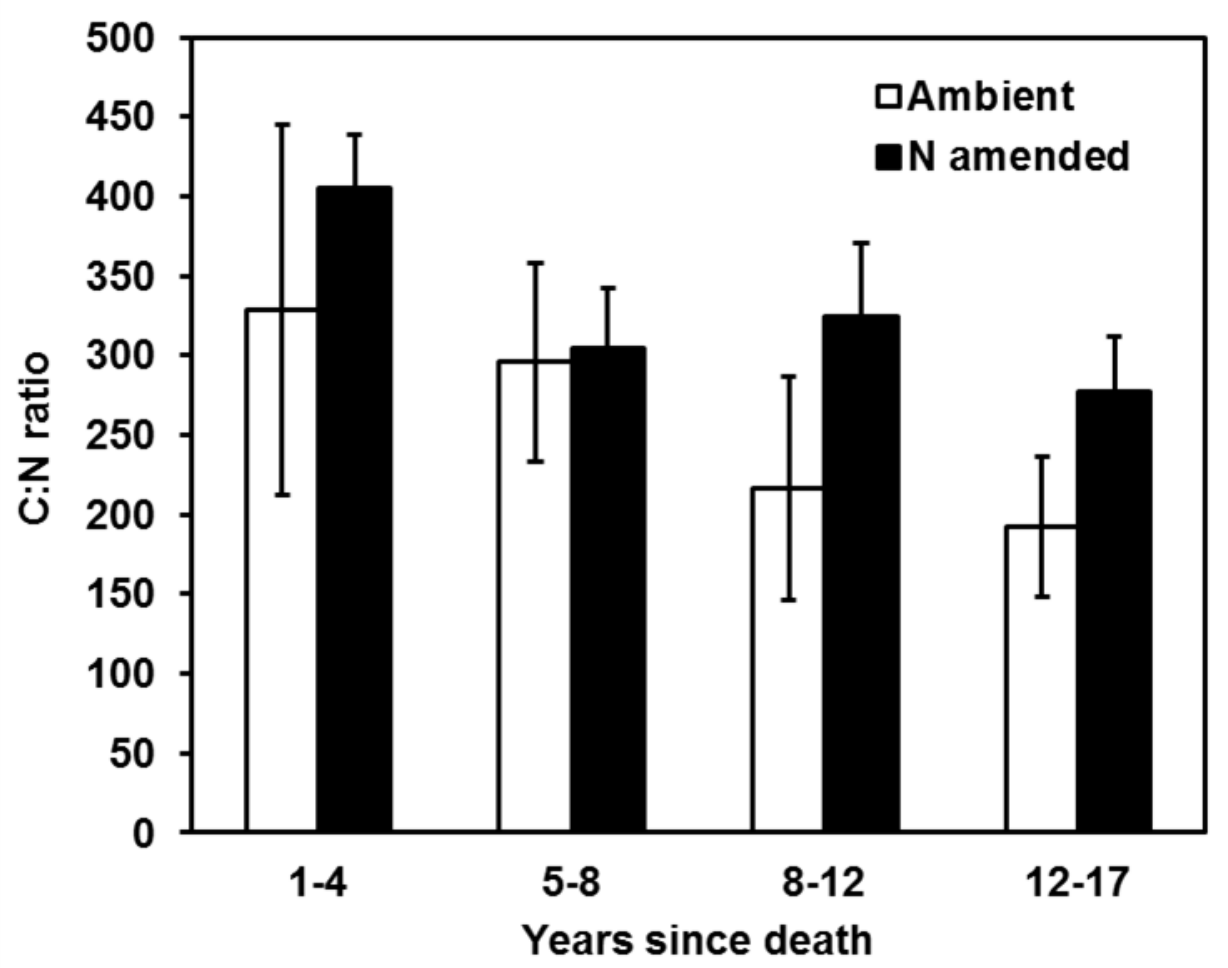

Figure 5. Comparison of carbon to nitrogen (C:N) ratios in wood samples from $\mathrm{N}$ amended and ambient treatments for each years since death class. Error bars indicate standard error within each treatment for years since death classes. 
Table 1. Climatic, floristic, and edaphic characteristics of four northern hardwood sites in Michigan

\begin{tabular}{|c|c|c|c|c|}
\hline \multirow[b]{2}{*}{ Location } & \multicolumn{4}{|c|}{ Site } \\
\hline & A & B & C & D \\
\hline Latitude, $\mathrm{N}$ & $46^{\circ} 52^{\prime}$ & $45^{\circ} 33^{\prime}$ & $44^{\circ} 23^{\prime}$ & $43^{\circ} 40^{\prime}$ \\
\hline Longitude, W & $88^{\circ} 53^{\prime}$ & $84^{\circ} 52^{\prime}$ & $85^{\circ} 50^{\prime}$ & $86^{\circ} 09^{\prime}$ \\
\hline \multicolumn{5}{|l|}{ Climate } \\
\hline Mean Annual Temperature $\left({ }^{\circ} \mathrm{C}\right)$ & 4.7 & 6 & 6.9 & 7.6 \\
\hline Mean Annual Precipiation (mm) & 873 & 871 & 888 & 812 \\
\hline Wet + Dry NO3 --N Deposition $\left(\mathrm{g} \mathrm{m}^{-2} \mathrm{y}^{-1}\right)$ & 0.38 & 0.58 & 0.78 & 0.76 \\
\hline Wet + Dry Total N Deposition $\left(\mathrm{g} \mathrm{m}^{-2} \mathrm{y}^{-1}\right)$ & 0.68 & 0.91 & 1.17 & 1.18 \\
\hline \multicolumn{5}{|l|}{ Vegatation } \\
\hline Overstory Biomass (Mg/ha) & 261 & 261 & 274 & 234 \\
\hline Acer saccharum Biomass (Mg/ha) & 237 & 224 & 216 & 201 \\
\hline \multicolumn{5}{|l|}{ Soil $(0-10 \mathrm{~cm})$} \\
\hline$\%$ Sand & 85 & 89 & 89 & 87 \\
\hline $\mathrm{pH}\left(1: 1\right.$ soil: $\left.\mathrm{H}_{2} \mathrm{O}\right)$ & 4.83 & 5.03 & 4.47 & 4.66 \\
\hline
\end{tabular}


Table 2. Two-way ANOVA results for site and $\mathrm{N}$ addition treatment as factors affecting wood density $\left(\mathrm{g} \mathrm{cm}^{-3}\right)$

\begin{tabular}{rccccc}
\hline \multicolumn{1}{r}{ Source } & df & $\begin{array}{c}\text { Sum-of- } \\
\text { Squares }\end{array}$ & $\begin{array}{c}\text { Mean- } \\
\text { Square }\end{array}$ & F-ratio & $\mathbf{P}$ \\
\hline Site & 3 & 0.327 & 0.109 & 3.9 & 0.012 \\
& & 0.125 & 0.125 & 4.485 & 0.038 \\
Treatment & 1 & 0.028 & 0.009 & 0.333 & 0.801 \\
Site ${ }^{\star}$ Treatment & 3 & 1.986 & 0.028 & & \\
error & 71 & & & &
\end{tabular}


Table 3. Two-way analysis of covariance (ANCOVA) results for the effects of site and treatment on wood density with years since death as a covariate

\begin{tabular}{rccccc}
\hline \multicolumn{1}{c}{ Source } & $\mathbf{d f}$ & $\begin{array}{c}\text { Sum-of- } \\
\text { Squares }\end{array}$ & $\begin{array}{c}\text { Mean- } \\
\text { Square }\end{array}$ & F-ratio & $\mathbf{P}$ \\
\hline Site & 3 & 0.402 & 0.134 & 5.848 & 0.001 \\
Treatment & 1 & 0.082 & 0.082 & 3.569 & 0.063 \\
Site*Treatment & 3 & 0.057 & 0.019 & 0.822 & 0.486 \\
Years since death & 1 & 0.382 & 0.382 & 16.662 & 0.000 \\
error & 70 & 1.604 & 0.023 & & \\
\hline
\end{tabular}


Table 4 Two-way analysis of covariance (ANCOVA) results for the effects of site and treatment on the carbon to nitrogen $(\mathrm{C}: \mathrm{N})$ ratio with years since death as a covariate

\begin{tabular}{rccccc}
\hline \multicolumn{1}{c}{ Source } & df & $\begin{array}{c}\text { Sum-of- } \\
\text { Squares }\end{array}$ & $\begin{array}{c}\text { Mean- } \\
\text { Square }\end{array}$ & F-ratio & $\mathbf{P}$ \\
\hline Site & 3 & 249520.698 & 83173.566 & 4.66 & 0.004 \\
Treatment & 1 & 64282.303 & 64282.303 & 3.602 & 0.060 \\
Site*Treatment & 3 & 109050.48 & 36350.16 & 2.037 & 0.112 \\
Years since & 1 & 203350.687 & 203350.687 & 11.394 & 0.001 \\
death & 1 & 2177274.102 & 17846.509 & & \\
error & 122 & 2170.5 & &
\end{tabular}


Chapter 3: An Assessment of Forest Stand Dynamics and Coarse Woody Debris Biomass Accumulation under Chronic Simulated Nitrogen

\section{Deposition}




\section{Introduction}

North American forests are expected to receive a 25\% increase in atmospheric nitrogen $(\mathrm{N})$ deposition in the coming decades (Galloway et al. 1994). Due to the combustion of fossil fuels and the use of $\mathrm{N}$ containing fertilizer, humans have significantly influenced the global $\mathrm{N}$ cycle. Both experimental additions of $\mathrm{N}$ in shortterm studies and chronic additions in long-term studies have found similar patterns in forest response to $\mathrm{N}$ amendments. In an analysis of 23 atmospheric chemistry transport models, Detener et al. (2006) states, “Currently 11\% of the world's natural vegetation receives $\mathrm{N}$ deposition in excess of the 'critical load' threshold of $1000 \mathrm{mg}(\mathrm{N}) \mathrm{m}^{-2} \mathrm{yr}^{-1}$;" the United States is considered one of the most affected regions.

A study from the University of Michigan’s Biological Station (UMBS) in northern lower Michigan calculated atmospheric $\mathrm{N}$ deposition from canopy $\mathrm{N}$ retention and soil $\mathrm{N}$ mineralization and found that atmospheric $\mathrm{N}$ inputs contribute up to $15 \%$ of NPP (Nave et al. 2009). Elevated N deposition has been found to increase aboveground net primary productivity (ANPP) (Nave et al. 2009; Pregitzer et al. 2008; Aber et al. 1995) in forests. This increase in productivity has resulted in an increase in aboveground live plus dead woody biomass (Pregitzer et al. 2008). Several studies have found that $\mathrm{N}$ amendments lead to an accumulation in forest floor organic matter (Berg and Matzner 1996; Franklin et al. 2003; Mansson and Falkengren-Grerup 2003). Pregitzer et al. (2008) recorded a 50\% increase in forest floor (Oi and Oe horizons) mass over a decade of $\mathrm{N}$ amendments. The increased mass of organic matter was concluded to be a physical barrier for sugar maple seedlings, effectively reducing sugar maple regeneration (Patterson et al. 2012). In $\mathrm{N}$ limited ecosystems, elevated $\mathrm{N}$ inputs have led to soil $\mathrm{N}$ saturation, an occurrence when soil solution $\mathrm{N}$ leaching nearly equals ecosystem $\mathrm{N}$ inputs (Pregitzer et al. 2004; Wallace et al. 2007; Aber et al. 1998; Garten 1999). Prolonged N saturation has been related to increases in tree mortality (Shen et al. 2001; Thomas et al. 2010; Wallace et al. 2007). Nissenan et al. (1999) speculated that initially tree growth would increase with $\mathrm{N}$ additions, but eventually it would decrease as other nutrients 
become limiting. Another pathway to increased mortality is that initial enhanced growth rates due to elevated $\mathrm{N}$ deposition could lead to increased competitive interactions within individuals. Those interactions would eventually result in some tree mortality through stem-exclusion, which can be accounted for via an assessment of CWD volume and biomass. The consequence of accelerated stand dynamics and associated self-thinning is a potential increase in the production of CWD.

Elevated $\mathrm{N}$ deposition has been correlated with reduced decomposition in leaf litter. Several studies have observed this result indirectly through reduced soil respiration (Burton et al., 2004; Cusack et al., 2010) and reduced heterotrophic microbial respiration (Janssens et al., 2010). Pregitzer et al. (2008) documented an accumulation of soil organic matter under experimental $\mathrm{N}$ deposition. Other research has found correlations with litter quality (Berg and Meetemeyer, 2002; Mansson and Falkengren-Grerup, 2003) enzyme activity (Waldrop et al., 2004; Carreiro et al., 2000; Wang et al., 2010; Sinsabaugh, 2010; DeForest et al., 2004), microbial genetic analyses (Blackwood et al., 2007; Hassett et al., 2009; Hofmockel et al., 2007), microbial biomass (Treseder, 2008; Zeglin et al. 2007), and reduced decomposition of coarse woody debris CWD (See Chapter 2).

\section{Objectives and hypotheses}

Few studies have directly assessed changes in the amount of dead woody biomass produced under conditions of chronic experimental elevated $\mathrm{N}$ deposition. We assessed tree mortality in a 17-year experimental $\mathrm{N}$ deposition study in northern hardwood forests. The objectives of this study were to determine if rates of biomass mortality were altered by the $\mathrm{N}$ deposition treatment and assess whether $\mathrm{N}$ deposition treatment led to an accumulation of CWD volume and biomass. We also evaluated changes over time in the average diameter of trees dying. Results were used to assess the influence of elevated $\mathrm{N}$ deposition on forest stand dynamics and carbon storage in CWD. We hypothesized that long term $\mathrm{N}$ amendments had significantly increased the amount of CWD production through enhanced tree mortality and had increased CWD biomass due to enhanced CWD 
inputs and reduced decomposition rates. We expect $\mathrm{N}$ amendments to accelerate stand dynamics largely by increasing mortality in the larger diameter at breast height (dbh) classes in recent years. 


\section{Methods}

Site description

The four study sites used in this research are located across a $500 \mathrm{~km}$ latitudinal gradient in Michigan (Figure 6). All four sites contain three $30 \mathrm{~m} \mathrm{x} 30 \mathrm{~m}$ treatment plots and three $30 \mathrm{~m}$ x $30 \mathrm{~m}$ control plots. Since 1994, elevated N-deposition has been simulated by broadcasting $0.5 \mathrm{~g} \mathrm{~N} \mathrm{~m}^{-2}$ month ${ }^{-1}$ of solid $\mathrm{NaNO}_{3}$ pellets in 6 equal applications during the growing season ( $3 \mathrm{~g} \mathrm{~N} \mathrm{~m}^{-2}$ annually). The sites receive total ambient $\mathrm{N}$ deposition ranging from 0.7 to $1.2 \mathrm{~g} \mathrm{~N} \mathrm{~m}^{-2} \mathrm{yr}^{-1}$ All sites contain similar flora, with the overstory dominated by Acer saccharum (80\% of basal area). Acer rubrum, Quercus rubra, Fagas grandifolia, and Prunus serotina are also common (Table 5). The four sites are northern hardwood forests (see Burton et al. 1991 for further information on site characteristics) with Kalkaska sand (Typic haploorthod) soils, similar age, and similar stand structure.

\section{Coarse Woody Debris Density}

All trees within each plot have been numbered, with diameter at breast height (dbh) measured annually at permanent marks since 1987 for ambient plots and since 1994 for $\mathrm{N}$ amended plots. Tree death has been recorded during annual measurements. Every tree within the study plots has known coordinates, which allowed them to be easily located. Wood from every third down dead tree dying between 1994 and 2011 was sampled during the summer of 2011. Decay classes 1 through 5 were used to classify down dead wood (DDW), or trees that died and are now lying on the forest floor. Decay class 1 indicated the tree was freshly fallen with bark and fine branches intact and often still having leaves. Decay class 2 was differentiated from decay class 3 by the presence of bark and secondary branches in decay class 2. Decay class 4 appeared slightly ellipsoidal with some fragmentation as well as evidence of insect and fungal attack. Decay class 5 was highly fragmented, often sunken in soil and moss covered. An extra class was used in addition to the decay classes 1 through 5. Decay class 9 was used to identify CWD 
which had been removed from a site by the public, presumably for use as firewood. Evidence of decay class 9 included cut CWD, wood chips from a chainsaw, and cut snag stumps.

Wood sampling for density analysis was done using either a chainsaw for decay classes 1 through 3 (sometimes 4 ), or steel core (5 cm diameter) for decay classes 4 and 5. A hole-saw or chisel was used to collect from every third dead standing tree (snag). Each visual decay class is intended to represent a relative level of decomposition for debris pieces (methods adapted from Duvall and Grigal 1999). Volume for density samples was calculated using dimension measurements from steel core samples and by water displacement on a balance for solid wood samples collected by the other methods. Samples were then placed in a drying oven at $65^{\circ} \mathrm{C}$ until a constant mass was achieved. Wood density $\left(\mathrm{g} \mathrm{cm}^{-3}\right)$ was obtained from volume and dry mass measurements.

\section{Coarse woody debris volume and biomass}

The “triangular transect” method described in Delisle et al. (1988) was employed to estimate DDW biomass at all sites during the 2012 field season. Each transect was an equilateral triangle with $30 \mathrm{~m}$ sides. Every piece of DDW $\geq 5 \mathrm{~cm}$ dbh was measured for diameter at the line intersection point and decay class. All six plots at each of the four sites were sampled (a total of 24 triangle transects). DDW volume was calculated as:

$$
V=(1.234) \times d^{2} / L
$$

Where $\mathrm{V}$ is volume $\left(\mathrm{m}^{3} / \mathrm{ha}\right)$, $\mathrm{d}$ is the diameter $(\mathrm{cm})$ of the piece of DDW measured perpendicular to the length of the log, and $\mathrm{L}$ is the length of transect $(90 \mathrm{~m}$ total in this case). Volume measurements as well as the previously noted density values calculated in the lab were used to estimate average biomass per treatment for each decay class. DDW volume and biomass data were analyzed with a three-way analysis of variance (ANOVA) with site, treatment, and decay class as factors. A two-way ANOVA (site by treatment) was done on total DDW biomass for each plot (sum of the five decay classes). 


\section{Mortality basal area}

For the 17 years of elevated $\mathrm{N}$ additions, tree mortality was recorded annually. That mortality is captured in our CWD analysis. To further examine the structure of forest mortality, we classified the diameters of all trees dying and used regression analysis to determine if the diameters of trees dying were changing over time and, if so, if there were differences among treatments in the rates of such changes. 


\section{Results}

\section{DDW biomass and volume}

Nitrogen additions did not have a significant effect on DDW volume (Table 7) or biomass (Table 8). DDW Volume decreased from site A to D; the relationship was marginally significant $(\mathrm{P}=0.075$, Table 7$)$. Down dead wood biomass declined from site A to site $\mathrm{D}$; although non-significant $(\mathrm{P}=0.155)$, this trend is important to note. DDW biomass differed significantly among decay classes (Figure 8). A significant decay class by site interaction also occurred $(\mathrm{P}=0.012)$. All treatment effects and interactions were non-significant (Table 6). The largest increase in DDW biomass from ambient to Namended plots occurred in decay classes 3 and 4 (987 kg ha ${ }^{-1}$ and $714 \mathrm{~kg} \mathrm{ha}^{-1}$ respectively, Figure 8). Assuming 50\% of biomass is carbon content of DDW, total carbon increased by $16 \%$ from ambient to $\mathrm{N}$-amended plots.

\section{Mortality and stand dynamics}

Across all sites, 52 more trees died in the $\mathrm{N}$ deposition treatment between 1994 and 2011 than in the ambient treatment, mostly occurring in sites C and D (Figure 7). The majority of mortality which occurred on both and ambient and $\mathrm{N}$-amended plots was found in the 6, 10, and $14 \mathrm{~cm}$ dbh classes (Figure 10). There was not a significant relationship between the year of tree death and their diameter. Both ambient and $\mathrm{N}$ amended mortality occurred evenly throughout the period of the Michigan Gradient study with a slight, non-significant increase in mortality in larger trees in more recent years (Figure 11). 


\section{Discussion}

\section{Biomass and volume}

Down dead wood biomass declined from site A to site D. The explanation for this is due in part to human removal at primarily the two southernmost sites (C and D). Although signs are displayed with statements that are meant to deter unnecessary human disturbance, several snags and DDW pieces were removed by the public (for firewood) during the study. Removed CWD accounts for 25\% of all dead trees surveyed, with $86 \%$ of removed trees taken from the two southern sites (C and D).

Research at the Michigan Gradient sites has indicated that dead wood density significantly differed in ambient and $\mathrm{N}$ amended treatments, with higher wood densities found in $\mathrm{N}$ amended plots (unpublished data). During 17 years of chronic experimental $\mathrm{N}$ deposition, DDW volume and biomass have accumulated in greater amounts in $\mathrm{N}$ amended plots (Figure 8). However, even though biomass and volume treatment effects were non-significant, we believe that DDW biomass is consistent with our hypothesis that DDW biomass will increase due to slower decomposition and resultant higher wood density. There was a 7\% decrease in DDW volume in $\mathrm{N}$ amended plots (Figure 9). When the significant differences in density (See Chapter 2) are taken into account when converting wood volume to biomass, there is a $16 \%$ increase in DDW biomass in $\mathrm{N}$ amended plots (Figure 8).

DDW volume is a highly variable forest characteristic; therefore we were unable to detect small differences between treatments. With this low power but a significant trend in wood density (see Chapter 2), it remains a possibility that DDW biomass may significantly increase under elevated $\mathrm{N}$ deposition. I conclude that as CWD density responds to $\mathrm{N}$ additions, biomass increases to a greater degree than volume and therefore may accumulate under $\mathrm{N}$ deposition. Due to reduced decomposition rates of DDW, I suspect that the $\mathrm{N}$ treatment effect on DDW biomass may become significant in the future. 


\section{Stand dynamics and mortality}

I hypothesized that chronic elevated $\mathrm{N}$ deposition would accelerate stand dynamics. If $\mathrm{N}$ limited individuals are exposed to ample amounts of readily available $\mathrm{N}$, they may grow faster. As trees grow faster, self-thinning may proceed more rapidly due to competition. This may result in enhanced mortality of intermediates and co-dominants. Eventually larger trees would begin to die, as they compete with each other. This trend likely wouldn’t appear until several years of enhanced aboveground NPP had occurred, as there is likely a lag time in stand structure response to competitive interactions. In our study plots, mortality generally occurred in the smaller dbh classes (Figure 10) as opposed to larger diameter classes. This is most likely a remnant of an earlier stem exclusion stage in stand development. Both $\mathrm{N}$ amended and ambient plots exhibited only minor differences in mortality in recent years (Figure 11). Although non-significant, the more recent mortality in both treated and ambient plots has included more individuals from larger dbh classes. This is most likely a result of natural shifts in stand dynamics and perhaps a "lag time" in accelerated stand dynamics for the $\mathrm{N}$ deposition treatment will take several more years, or even decades to become distinguishable.

\section{Carbon storage}

Several studies have concluded that $\mathrm{N}$ deposition increases $\mathrm{C}$ storage in forests. Although statistically non- significant, CWD in our N amended plots stored $16 \%$ more C than in ambient plots. Elevated $\mathrm{N}$ deposition increased in C storage by 26\% in northern hardwood forests due to enhanced tree growth in combination with reductions in decomposition and associated increases in forest floor and surface soil organic matter (Pregitzer et al. 2008). Thomas et al. (2009) used forest inventory data to estimate the degree of carbon storage in trees along an $\mathrm{N}$ deposition gradient in the United States. The analysis found that "above-ground biomass increment increased by $61 \mathrm{~kg}$ of $\mathrm{C}$ per $\mathrm{kg}$ of $\mathrm{N}$ deposited." When this number is expanded to the global level, $\mathrm{N}$ deposition could potentially increase $\mathrm{C}$ storage in trees by an extra $0.31 \mathrm{Pg}$ carbon $\mathrm{yr}^{-1}$. Because $\mathrm{N}$ 
additions have led to increased relative recalcitrance of lignin (Berg and Matzner 1997; Stevenson 1982), increased tree mortality (Shen et al. 2001; Thomas et al. 2010; Wallace et al. 2007), and reduced decomposition of DDW (see Chapter 2), DDW could play a significant role in forest $\mathrm{C}$ storage under future levels of $\mathrm{N}$ deposition. With this in mind, forest $\mathrm{C}$ models should be amended to consider the portion of $\mathrm{C}$ retained in CWD.

\section{Implications for management}

Forest managers examine coarse woody debris for a variety of reasons. The U.S. Forest Service uses CWD as part of their estimates of forest carbon storage (Smith et al. 2002). Others are concerned with climate change and carbon sequestration. $\mathrm{N}$ deposition has the potential to increase carbon stored as CWD by reducing CWD decomposition (unpublished data). Downed dead wood and snags provide habitat and nesting sites for a variety of birds (Rosenberg et al. 1988; Swallow et al.1988), small mammals (Zollner and Crane 2003; Smith and Maguire 2004), amphibians (Dupuis et al. 1995; Butts and McComb 2000; Moseley et al. 2004), and invertebrates (Jonsell and Weslien 2003; Jabin et al. 2004). $\mathrm{N}$ amendments disrupt the decomposition of CWD (see Chapter 2), which may or may not influence an organism's ability to utilize it for resources. $\mathrm{N}$ amendments have in some cases led to greater tree mortality (Shen et al. 2001; Thomas et al. 2010; Wallace et al. 2007). Although research is needed in order to quantify this, perhaps $\mathrm{N}$ deposition will increase available wildlife habitat over time. Accumulations of CWD are common in old growth forests. The Michigan gradient plots are unmanaged secondgrowth forests (Burton et al. 1991) currently undergoing understory reinitiation. Over time, $\mathrm{N}$ deposition may lead to greater structural complexity in unmanaged secondgrowth and essentially push the stand closer to old-growth-like characteristics (purely structural), which may be of interest to those managing for the creation of old-growthlike conditions. More research is needed in order to understand if, and to what extent, $\mathrm{N}$ deposition increases wildlife habitat, increase carbon storage, and structural complexity in forests. 


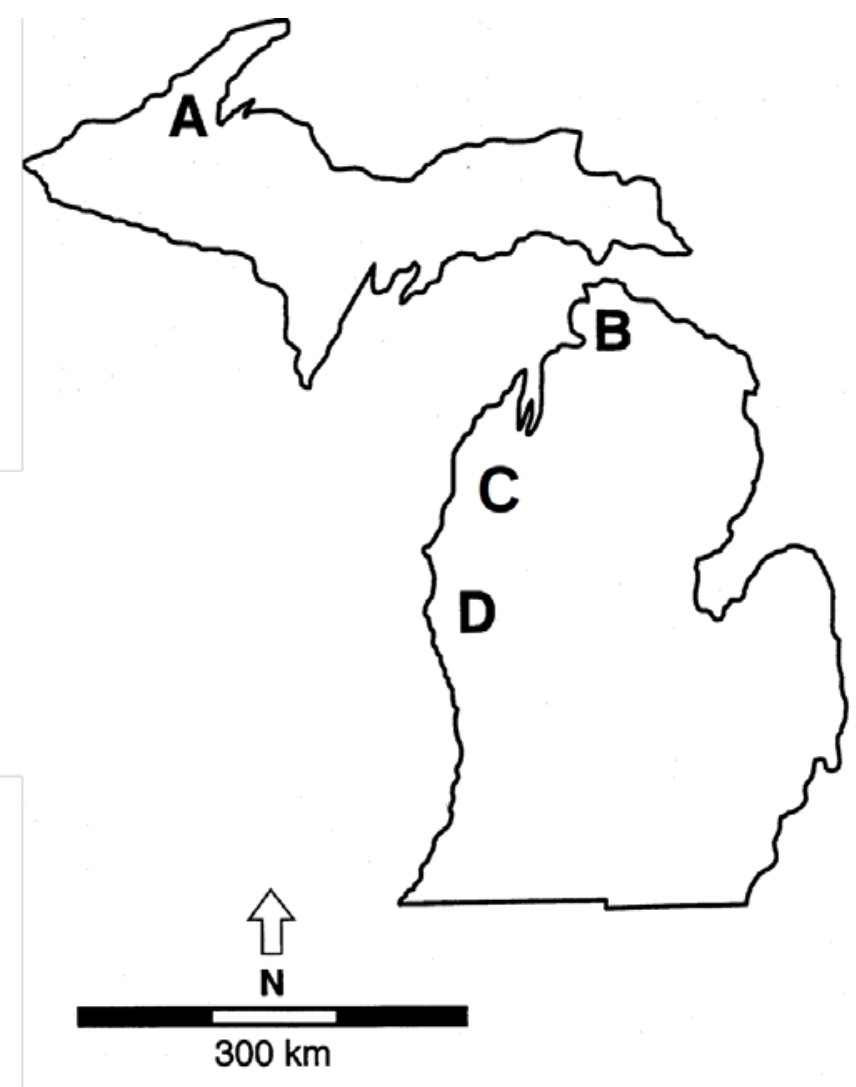

Figure 6. Four replicate sites along a north-south climatic gradient in Michigan have been receiving chronic elevated $\mathrm{N}$ additions since 1994. $\mathrm{N}$ amendments are in the form of solid $\mathrm{NaNO}_{3}$ pellets, applied in 6 equal increments during the growing season $\left(3 \mathrm{~g} \mathrm{~N} \mathrm{~m}^{-2}\right.$ annually). 


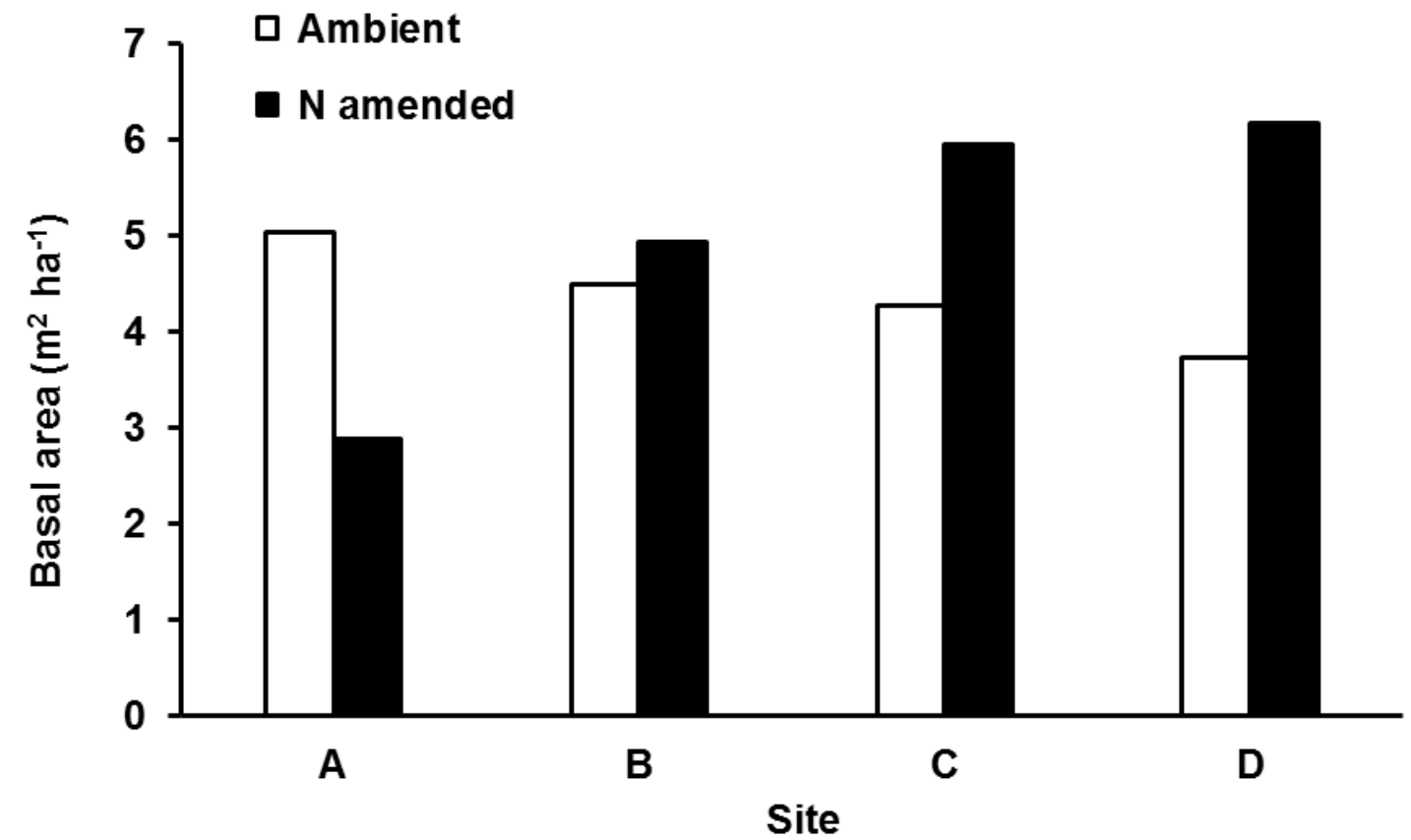

Figure 7. Mortality basal area per hectare at sites A through D. Values are based on the dbhs of all trees dying from 1994 through 2011. 


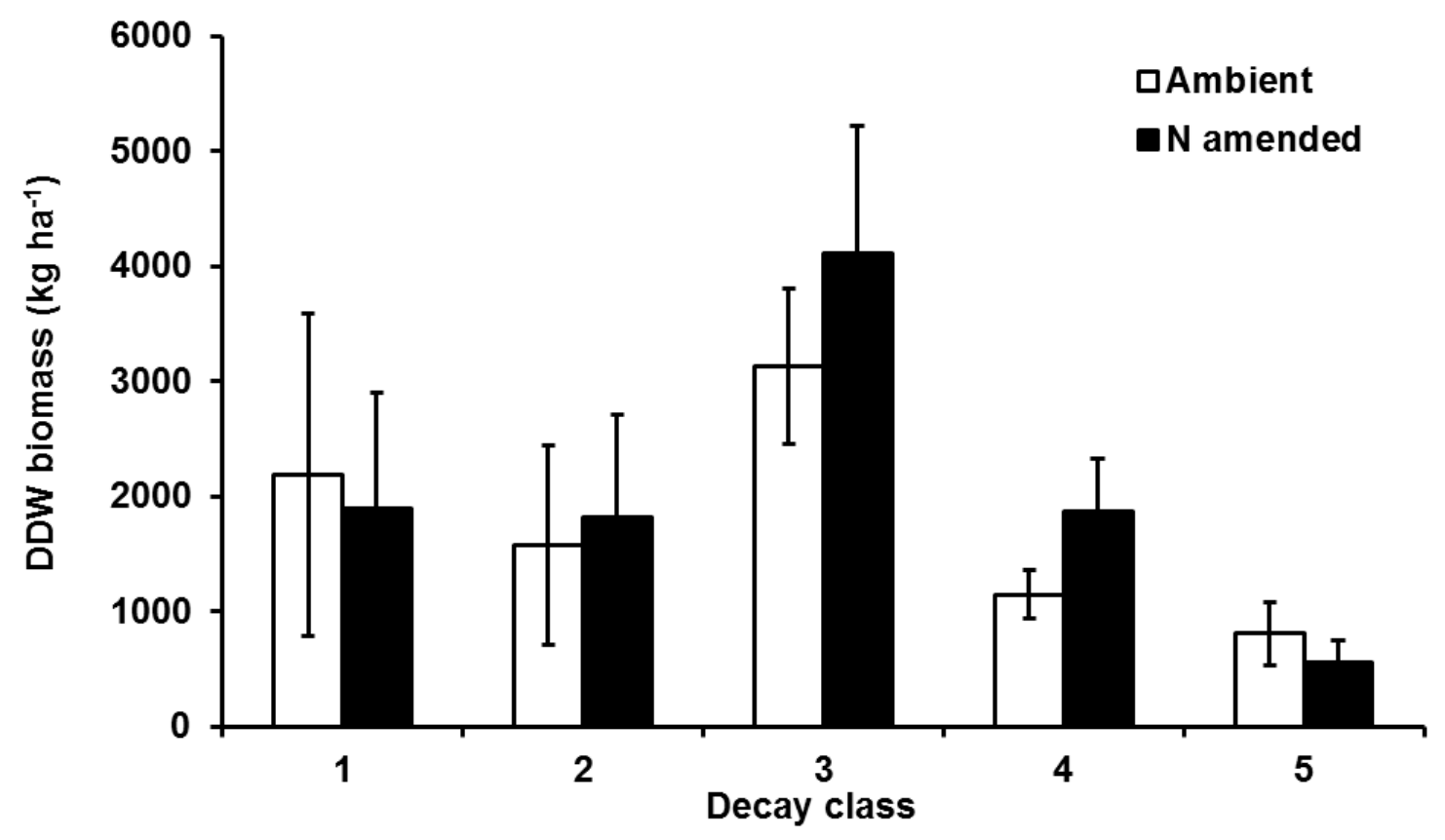

Figure 8. Average DDW biomass per hectare by decay class for $\mathrm{N}$ amended and ambient treatments. Error bars indicate \pm 1 standard error of the mean. 


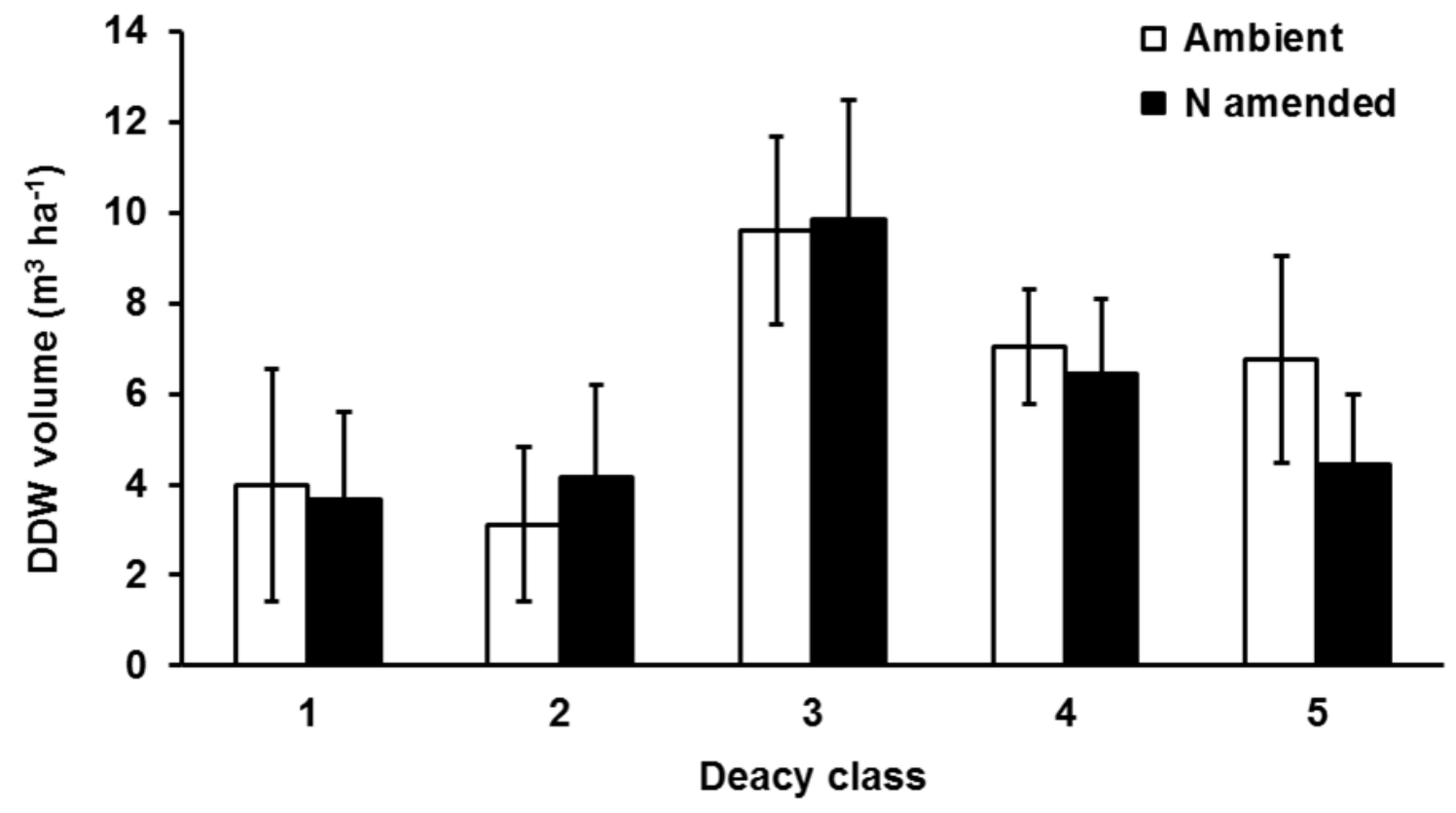

Figure 9. Average DDW volume $\left(\mathrm{m}^{3}\right.$ ha $\left.\mathrm{a}^{-1}\right)$ in $\mathrm{N}$ amended and ambient treatments by decay classes surveyed in 2012 . Error bars indicate \pm 1 standard error of the mean. 


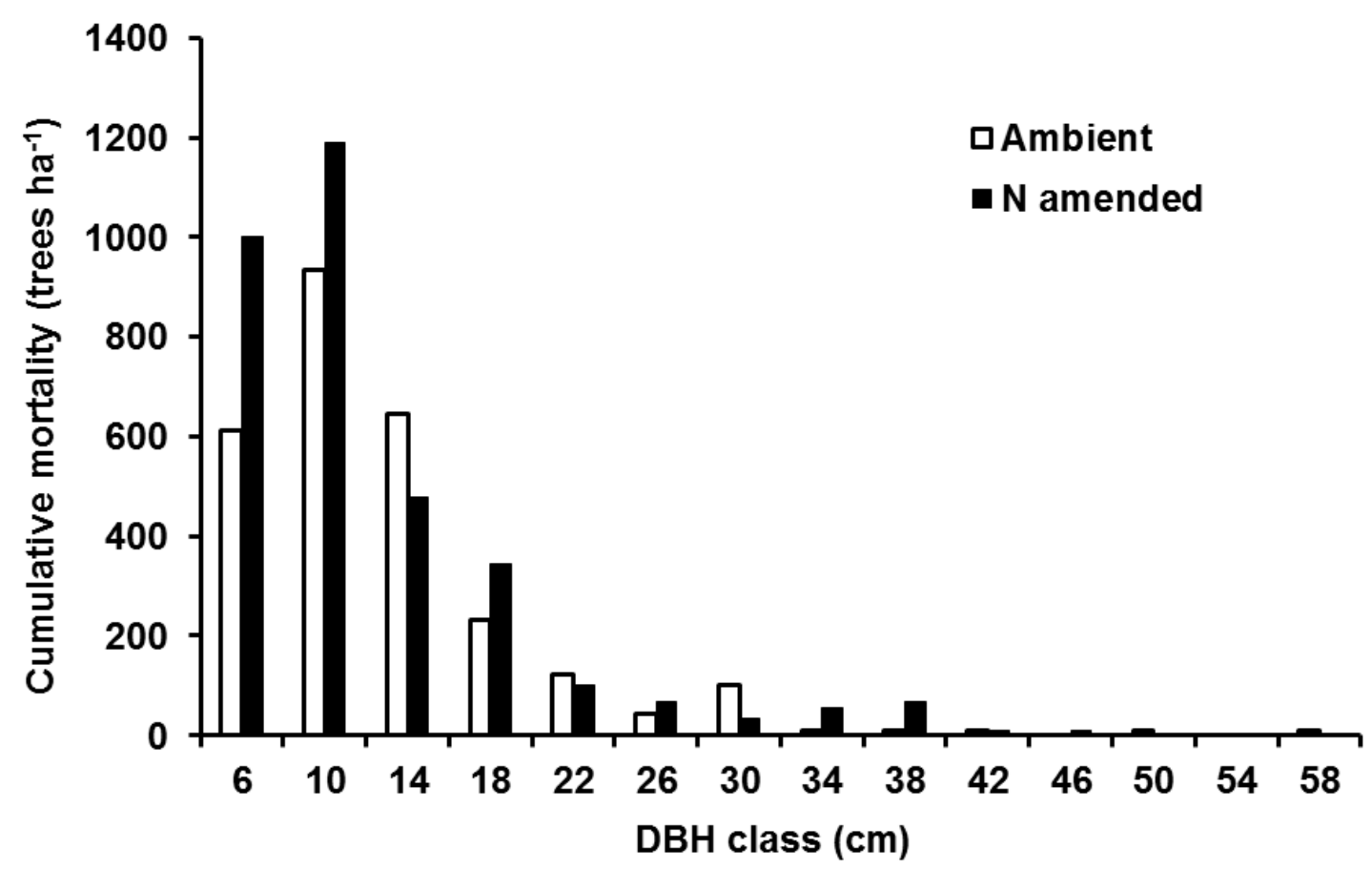

Figure 10. Diameter distribution for cumulative tree mortality from 1994 through 2011 for the control and $\mathrm{N}$ deposition treatments 


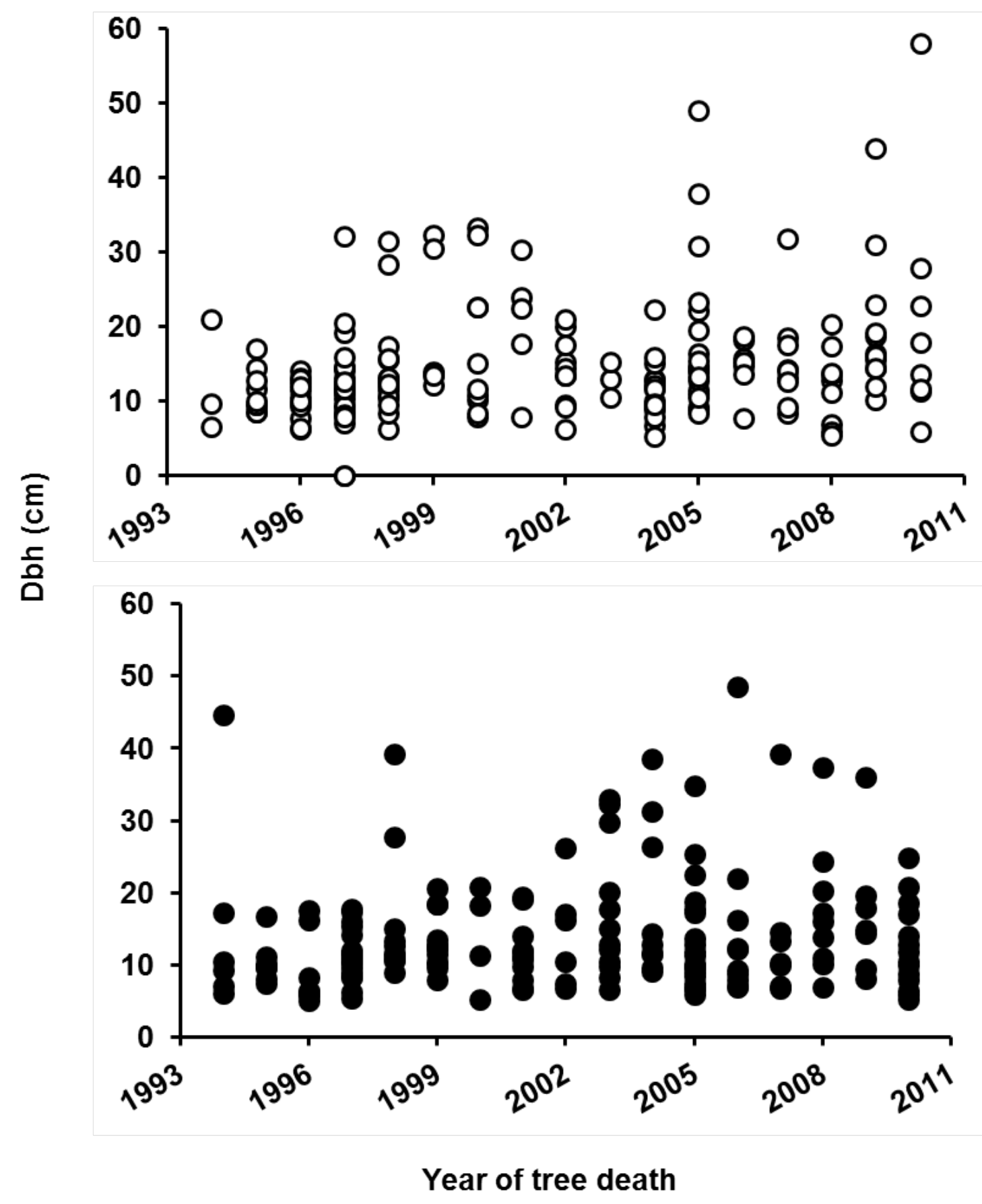

Figure 11. Diameter of trees dying plotted against the year of tree mortality for ambient and $\mathrm{N}$ amended treatments. 
Table 5. Climatic, floristic, edaphic characteristics of four northern hardwood forests in Michigan

\begin{tabular}{|c|c|c|c|c|}
\hline \multirow[b]{2}{*}{ Location } & \multicolumn{4}{|c|}{ Site } \\
\hline & A & B & C & D \\
\hline Latitude, $\mathrm{N}$ & $46^{\circ} 52^{\prime}$ & $45^{\circ} 33^{\prime}$ & $44^{\circ} 23^{\prime}$ & $43^{\circ} 40^{\prime}$ \\
\hline Longitude, W & $88^{\circ} 53^{\prime}$ & $84^{\circ} 52^{\prime}$ & $85^{\circ} 50^{\prime}$ & $86^{\circ} 09^{\prime}$ \\
\hline \multicolumn{5}{|l|}{ Climate } \\
\hline Mean Annual Temperature $\left({ }^{\circ} \mathrm{C}\right)$ & 4.7 & 6 & 6.9 & 7.6 \\
\hline Mean Annual Precipiation (mm) & 873 & 871 & 888 & 812 \\
\hline Wet + Dry NO3 --N Deposition $\left(\mathrm{g} \mathrm{m}^{-2} \mathrm{y}^{-1}\right)$ & 0.38 & 0.58 & 0.78 & 0.76 \\
\hline Wet + Dry Total N Deposition $\left(\mathrm{g} \mathrm{m}^{-2} \mathrm{y}^{-1}\right)$ & 0.68 & 0.91 & 1.17 & 1.18 \\
\hline \multicolumn{5}{|l|}{ Vegatation } \\
\hline Overstory Biomass (Mg/ha) & 261 & 261 & 274 & 234 \\
\hline Acer saccharum Biomass (Mg/ha) & 237 & 224 & 216 & 201 \\
\hline \multicolumn{5}{|l|}{ Soil $(0-10 \mathrm{~cm})$} \\
\hline$\%$ Sand & 85 & 89 & 89 & 87 \\
\hline $\mathrm{pH}\left(1: 1\right.$ soil: $\left.\mathrm{H}_{2} \mathrm{O}\right)$ & 4.83 & 5.03 & 4.47 & 4.66 \\
\hline
\end{tabular}


Table 6. Three-way ANOVA results for the effects of site, treatment, and decay class on DDW biomass

\begin{tabular}{|c|c|c|c|c|c|}
\hline Source & df & $\begin{array}{l}\text { Sum-of- } \\
\text { Squares }\end{array}$ & $\begin{array}{l}\text { Mean- } \\
\text { Square }\end{array}$ & F-ratio & $\mathbf{P}$ \\
\hline Site & 3 & $3.656 \cdot 10^{7}$ & $1.219 \cdot 10^{7}$ & 1.793 & 0.155 \\
\hline Treatment & 1 & $2.383 \cdot 10^{6}$ & $2.383 \cdot 10^{6}$ & 0.351 & 0.555 \\
\hline Decayclass & 4 & $1.117 \cdot 10^{8}$ & $2.792 \cdot 10^{7}$ & 4.109 & 0.004 \\
\hline Site ${ }^{\star}$ Treatment & 3 & $2.506 \cdot 10^{7}$ & $8.353 \cdot 10^{6}$ & 1.229 & 0.305 \\
\hline Site*Decay class & 12 & $1.912 \cdot 10^{8}$ & $4.594 \cdot 10^{7}$ & 2.345 & 0.012 \\
\hline \multirow{2}{*}{$\begin{array}{r}\text { Treatment*Decay class } \\
\text { Site*Treatment*Decay } \\
\text { class }\end{array}$} & 4 & $7.778 \cdot 10^{6}$ & $1.994 \cdot 10^{6}$ & 0.286 & 0.886 \\
\hline & 12 & $7.167 \cdot 10^{7}$ & $5.972 \cdot 10^{6}$ & 0.879 & 0.571 \\
\hline Error & 80 & $5.437 \cdot 10^{8}$ & $6.796 \cdot 10^{6}$ & & \\
\hline
\end{tabular}


Table 7. Three-way ANOVA results for DDW volume $\left(\mathrm{m}^{-3} \mathrm{ha}^{-1}\right)$ with site, treatment, and decay class as factors

\begin{tabular}{rccccc}
\hline Source & df & SS & MS & F-ratio & P \\
Site & 3 & 316.327 & 105.442 & 2.385 & 0.075 \\
Treatment & 1 & 4.525 & 4.525 & 0.102 & 0.750 \\
Decay class & 4 & 596.286 & 149.072 & 3.372 & 0.013 \\
Site*Treatment & 3 & 69.728 & 23.243 & 0.526 & 0.666 \\
Site*Decay class & 12 & 977.322 & 81.444 & 1.842 & 0.055 \\
Treatment*Decay class & 4 & 37.211 & 9.303 & 0.21 & 0.932 \\
Site*Treatment*Decay class & 12 & 456.685 & 38.057 & 0.861 & 0.589 \\
error & 80 & 353.164 & 44.215 & & \\
\hline
\end{tabular}


Table 8. Two-way ANOVA results for total DDW biomass (summed across decay classes) with site and treatment as factors

\begin{tabular}{rccccc}
\hline \multicolumn{1}{c}{ Source } & Df & $\begin{array}{c}\text { Sum-of } \\
\text { Squares }\end{array}$ & $\begin{array}{c}\text { Mean- } \\
\text { Square }\end{array}$ & F-ratio & P \\
\hline Site & 3 & $1.828 \cdot 10^{8}$ & $6.093 \cdot 10^{7}$ & 1.216 & 0.336 \\
Treatment & 1 & $1.191 \cdot 10^{7}$ & $1.191 \cdot 10^{7}$ & 0.238 & 0.632 \\
Site*Treatment & 3 & $1.252 \cdot 10^{8}$ & $4.176 \cdot 10^{7}$ & 0.834 & 0.495 \\
error & 16 & $8.016 \cdot 10^{8}$ & $5.010 \cdot 10^{7}$ & & \\
\hline
\end{tabular}


Table 9. Two-way ANOVA for total DDW volume (summed across decay classes) with site and treatment as factors

\begin{tabular}{rccccc}
\hline \multicolumn{1}{c}{ Source } & Df & $\begin{array}{c}\text { Sum-of- } \\
\text { Squares }\end{array}$ & $\begin{array}{c}\text { Mean- } \\
\text { Square }\end{array}$ & F-ratio & P \\
\hline Site & 3 & 1581.635 & 527.212 & 1.737 & 0.200 \\
Treatment & 1 & 22.624 & 22.624 & 0.075 & 0.788 \\
Site*Treatment & 3 & 348.642 & 116.214 & 0.383 & 0.767 \\
error & 16 & 4857.285 & 303.580 & & \\
\hline
\end{tabular}




\section{Thesis Conclusions}

Experimental $\mathrm{N}$ deposition affected DDW wood density and wood C:N ratios and subsequently reduced the decomposition of DDW in northern temperate forests (Chapter 2). The reduction in decomposition was likely due to an inhibition of white-rot fungi by elevated $\mathrm{N}$ additions. Wood density and wood C:N ratio data sets are independent of each other. Any bias or error in wood density resulting from errors in volume estimates would not affect wood C:N ratios, yet both data sets yielded similar results. Long term $\mathrm{N}$ deposition studies on wood degrading fungi within DDW are needed to confirm if elevated $\mathrm{N}$ inputs inhibited white-rot fungal enzyme activity, shifted community composition, or modified the structure of lignin in DDW. Elevated N deposition has the potential to increase DDW biomass in part by accelerating stand dynamics, ultimately enhancing DDW inputs from mortality, especially that of larger diameter trees. Further research on forest stand dynamics under long-term elevated $\mathrm{N}$ deposition is needed to confirm this. Reduced decomposition of DDW and accumulating dead woody biomass

could increase $\mathrm{C}$ sequestration in northern temperate forests. $\mathrm{N}$ deposition effects on DDW dynamics should be included in forest C models, using realistic scenarios for future levels of $\mathrm{N}$ deposition. 


\section{References}

Aber, J.D., K.J. Nadelhoffer, P. Steudler, J.M. Melillo. 1989. Nitrogen saturation in northern forest ecosystems. BioScience 39:378-386.

Aber, J.D., W. McDowell, K. Nadelhoffer, A. Magill, G.Berntson, M. Kamakea, S. McNulty, W. Currie, L. Rustad, I. Fernandez. 1998. Nitrogen saturation in temperate forest ecosystems. Bioscience 48: 921-934.

Aber, J.D., A. Magill, S.G. Mcnulty, R.D. Boone, K.J. Nadelhoffer, M. Downs, R. Hallett. 1995. Forest biogeochemistry and primary production altered by nitrogen saturation. Water, Air and Soil Pollution 85: 1665-1670.

Barford C.C., S.C. Wofsy, M.L. Goulden, J.W. Munger, E. Hammond Pyle, S.P. Urbanski, L. Hutyra, S.R. Saleska, D. Fitzjarrald, K. Moore. 2001. Factors controlling long- and short-term sequestration of atmospheric $\mathrm{CO}_{2}$ in a midlatitude forest. Science 294: 1688-1691.

Barnes, B.V., D.R. Zak, S.R. Denton, S.H. Spurr. Forest Ecology. 1998. $4^{\text {th }}$ edition. John Wiley \& Sons Inc.

Berg, B. and E. Matzner. 1997. Effect of $\mathrm{n}$ deposition on decomposition of plant litter and soil organic matter in forest systems. Environmental Review 5:1-25.

Berg, B. and V. Meentemeyer. 2002. Litter quality in a north European transect versus carbon storage potential. Plant and Soil 242: 83-92.

Brady, N.C., R. R. Weil. 2008. The Nature and Properties of Soil. 14th edition. Prentice Hall.

Blackwood, C.R., M.P. Waldrop, D.R. Zak, R.L. Sinsabaugh. 2007. Molecular analysis of fungal communities and laccase genes in decomposing litter reveals differences among forest types but no impact of nitrogen deposition. Environmental Microbiology 9: 1306-1316. 
Boominathan, K., S. Balachandra Dass, T.A. Randall, C.A. Reddy. 1990. Nitrogenderegulated mutants of Phanerochaete chrysosporium - a lignin degrading basidiomycete. Archives of Microbiology 153: 521-527.

Burton, A.J., C.W. Ramm, D.D. Reed, and K.S. Pregitzer. 1991. Use of multivariate methods in forest research site selection. Canadian Journal of Forest Research 21:1573-1580.

Burton, A.J., K.S. Pregitzer, J.N. Crawford, G.P. Zogg, D.R. Zak. 2004. Simulated chronic NO3- deposition reduces soil respiration in northern hardwood forests. Global Change Biology 10: 1080-1091.

Butts, S.R., McComb, W.C., 2000. Association of forest-floor vertebrates with coarse woody debris in managed forests of western Oregon. Journal of Wildlife Management 64: 95-104.

Campbell, W.G. 1930. The chemistry of the white rots of wood. The effect on wood substance of Polystictus versicolor (LINN) FR. Biochemistry 24: 1235-1243.

Carreiro, M.M., R.L. Sinsabaugh, D.A. Repert, D.F. Parkhurst. 2000. Microbial enzyme shifts explain litter decay responses to simulated N deposition. Ecology 81: 23592365.

Catovsky, S., R.K. Kobe, F.A. Bazzaz. 2002. Nitrogen-induced changed in seedling regeneration and dynamics of mixed conifer-broad-leaved forests. Ecological Applications 12: 1611-1625.

Currie, W.S., K.J. Nadelhoffer, J.D. Aber. 2004. Redistributions of $15 \mathrm{~N}$ highlight turnover and replenishment of mineral soil organic $\mathrm{N}$ as a long-term control on forest C balance. Forest Ecology and Management 196: 109-127.

Cusack, D.F., M.S. Torn, W.H. Mcdowell, W.L. Silver. 2010. The response of heterotrophic activity and carbon cycling to $\mathrm{N}$ additions and warming in two tropical soils. Global Change Biology 16: 2555-2572. 
Creed, I.F., K.L. Webster, D.L. Morrison. 2004. A comparison of techniques for measuring density and concentrations of carbon and nitrogen in coarse woody debris at different stages of decay. Canadian Journal of Forest Research 34:744753.

Delisle, G.P., P.M. Woodard, S.J. Titus, A.F. Johnson. 1988. Sample size and variability of fuel weight estimates in natural stands of lodgepole pine. Canadian Journal of Forest Research 18: 649-652.

DeForest, J.L., D.R. Zak, K.S. Pregitzer, A.J. Burton. 2004. Atmospheric nitrate deposition, microbial community composition, and enzyme activity in northern hardwood forests. Soil Science Society of America 68: 132-138.

Detener et al. 2006. Nitrogen and sulfur deposition on regional and global scales: A multimodel evaluation. Global Biogeochemical Cycles 20: GB4003, doi:10.1029/2005GB002672.

Dupuis, L.A., J.N.M. Smith, F. Bunnell. 1995. Relation of terrestrial-breeding amphibian abundance to tree-stand age. Conservation Biology 9: 645-653.

Duvall M.D. and D.F. Grigal. 1999. Effects of timber harvesting on coarse woody debris in red pine forests across the Great Lakes states, U.S.A. Canadian Journal of Forest Research 29:1926-1934.

Fenn M.E., M.A. Poth, J.D. Aber, J.S. Baron, B.T. Bormann, D.W. Johnson, A.D. Lemly, S.G. McNulty, D.F. Ryan, R. Stottlemyer. 1998. Nitrogen excess in North American ecosystems: predisposing factors, ecosystem responses, and management strategies. Ecological Applications 8: 706-733

Frey, S.D., M. Knorr, J. Parent, R.T. Simpson. 2004. Chronic nitrogen enrichment affects the structure and function of the soil microbial community in a forest ecosystem. Forest Ecology and Management 196: 159-171. 
Gallo, M., R. Amonette, C. Lauber, R.L. Sinsabaugh, D.R. Zak. 2004. Microbial community structure and oxidative enzymatic activity in nitrogen-amended north temperate forest soils. Microbial Ecology 48: 218-229.

Galloway, J.N., H. Levy, II, P.S. Kasibhatla. 1994. Year 2020: Consequences of population growth and development on deposition of oxidized N. Ambio. 23: 120-123.

Galloway, J.N., F.J. Dentener, D.G. Capone, E.W. Boyer, R.W. Horwath, S.P. Seitzinger, G.P. Asner, C.C. Cleveland, P.A. Green, E.A. Holland, D.M. Karl, A.F. Michaels, J.H. Porter, A. R. Townsend, C.J. Vörösmarty. 2004. N cycles; past, present and future. Biogeochemistry 70: 153-226.

Ganjegunte, G.K., L.M. Condron, P.W. Clinton, M.R. Davis, N. Mahieu. 2004. Decomposition and nutrient release from radiata pine (Pinus radiate) coarse woody debris. Forest Ecology and Management 187: 197-211.

Garten, C.T. 2000. Nitrogen saturation and soil N availability in a high-elevation spruce and fir forest. Water, Air, and Soil Pollution 120: 295-313.

Hassett, J.E., D.R. Zak, C.B. Blackwood, K.S. Pregitzer. 2009. Are basidiomycete laccase gene abundance and composition related to reduced lignolytic activity under elevated atmospheric NO3- deposition in a northern hardwood forest? Microbial Ecology 57: 728-739.

Hammel, K.E. 1997. “Chapter 2: Fungal degradation of lignin.” G. Cadisch \& K.E. Giller (Eds.). Driven by Nature: Plant Litter Quality and Decomposition (33-45). CAB International. 1997.

Hofmockel, K.S., D.R. Zak, C.R. Blackwood. 2007. Does atmospheric NO3- deposition alter the abundance and activity of ligninolytic fungi in forest soils? Ecosystems 10: 1278-1286. 
Hogberg, P., H. Fan, M. Quist, D. Binkley, C.O. Tamm. 2006. Tree growth and soil acidification in response to 30 years of experimental nitrogen loading on boreal forest. Global Change Biology 12: 489-499.

Hogberg, P. 2007. N impacts on forest carbon. News and Views. Nature 44: 781-782.

Horwath, W. 2007. "Carbon cycling and formation of soil organic matter." Soil Microbiology and Biochemistry. $3^{\text {rd }}$ edition. Burlington, MA: Academic Press, 2007. 303-467.

Jabin, M., Mohr, D., Kappes, H., Topp, W., 2004. Influence of deadwood on density of soil macro-arthropods in a managed oak-beech forest. Forest Ecology and Mangement. 194: 61-69.

Janssens, I.A., W. Dieleman, S. Luyssaert, J-A. Subke, M. Reichstein, R. Ceulemans, P. Cias, A.J. Dolman, J. Grace, G. Matteucci, D. Papale, S.L. Piao, E-D. Schulze, J. Tang, B.E. Law. 2010. Reduction of forest soil respiration in response to nitrogen deposition. Nature geoscience 3: DOI:10.1038/NGEO844.

Johannes, M., H. Knopps, S. Naeem, P.B. Reich. 2007. The impact of elevated CO2, increased nitrogen availability and biodiversity on plant tissue quality and decomposition. Global Change Biology 13: 1960-1971.

Jonsell, M., J. Weslien. 2003. Felled or standing retained wood—it makes a difference for saproxylic beetles. Forest Ecology and Management. 175: 425-435.

Knorr, M., S.D. Frey, P.S. Curtis. 2005. Nitrogen additions and litter decomposition: A meta-analysis. Ecology 86: 3252-3257.

Lauber, C.L., R.L. Sinsabaugh, D.R. Zak. 2009. Laccase gene composition and relative abundance in oak forest soil is not affected by short term $\mathrm{N}$ fertilization. Microbial Ecology 57: 50-57. 
Lucas, R.W. and B.B. Casper. 2008. Ectomycorrhizal community and extracellular enzyme activity following simulated atmospheric $\mathrm{N}$ deposition. Soil Biology and Biochemistry 40: 1662-1669.

Mansson, K.F., and U. Falkengren-Grerup. 2003 The effect of nitrogen deposition on nitrification, carbon and nitrogen mineralisation and litter $\mathrm{C}: \mathrm{N}$ ratios in oak (Quercus robur L.) forests. Forest Ecology and Management 179: 455-476.

Magill, A.H., J.D. Aber, J.J. Hendricks, R.D. Bowden, J.M. Melillo, P.A. Steudier. 1997. Biogeochemical response of forest ecosystems to simulated chronic nitrogen deposition. Ecological Applications 7: 402-415.

Magnani, F., M. Mencuccini, M. Borghetti. et al. 2007. The human footprint in the carbon cycle of temperate and boreal forests. Nature 477: 848-850.

Melillo, J.M., J.D. Aber, J.F. Muratore. 1982. Nitrogen and lignin control of hardwood leaf litter decomposition dynamics. Ecology 63: 621-626.

Meetenmeyer, V. 1978. Macroclimate the lignin control of litter decomposition rates. Ecology 59: 465-472.

Moseley, K.R., S.B. Castleberry, W.M. Ford, W.M., 2004. Coarse woody debris and pine litter manipulation effects on movement and microhabitat use of Ambystoma talpoideum in a Pinus taeda stand. Forest Ecology and Management 191: 387396.

Myneni, R.B., J. Dong, C.J. Tucker, R.K. Kaufmann, P.E. Kauppi, J. Liski, L. Zhou, V. Aleneyev, and M.K. Hughes. 2001. A large carbon sink in the woody biomass of northern forests. PNAS. 98: 14784-14789.

Nave, L.E., C.S. Vogel, C.M. Gough, P.S. Curtis. 2009. Contribution of atmospheric N deposition to net primary productivity in northern hardwood forest. Canadian Journal of Forestry 39: 1108-1118. 
Nissenan, A., P. Hari. 1998. Effects of nitrogen deposition on tree growth and soil nutrients in boreal Scots pine stands. Environmental pollution. 102: 61-68.

Osono, T. 2007. Ecology of ligninolytic fungi associated with leaf litter decomposition. Ecological Research 22: 955-974.

Patterson, S.L., D.R. Zak, A.J. Burton, A.F. Talheim, K.S. Pregitzer. 2012. Simulated N deposition negatively impacts sugar maple regeneration in a northern hardwood ecosystem. Journal of Applied Ecology 49: 155-163.

Pregitzer, K.S., D.R. Zak, A.J. Burton, and J.A. Ashby. 2004. Chronic nitrate additions dramatically increase the export of carbon and nitrogen in northern hardwood forests. Biogeochemistry 68:179-197.

Pregitzer, K.S., A.J. Burton, D.R. Zak A.F. Talhelm. 2008. Simulated chronic N deposition increases carbon storage in northern temperate forests. Global Change Biology 14: 142-153.

Saiya-Cork, K.R., R.L. Sinsabaugh, D.R. Zak. 2002. The effects of long term nitrogen deposition on extracellular enzyme activity in an Acer saccharum forest soil. Soil Biology and Biochemistry 34: 1309-1315.

Schmidt, M.W.I., M.S. Torn, S Abiven, T. Dittmar, G. Guggenberger, I.A. Janssens, M. Kleber, I.J. Kogel-KnabnerLehmann, D.A.C. Manning, P. Nannipieri, D.P. Rasse, S. Weiner, S.E. Trumbore. 2011. Persistence of soil organic matter as an ecosystem property. Nature 478: 49-56.

Shen, G., J.A. Moore, C.R. Hatch. 2001. The effect of nitrogen fertilization, rock type, and habitat type on individual tree mortality. Forest Science 47: 203-213.

Sinsabaugh, R.L., M.M. Carreiro, D.A. Repert. 2002. Allocation of extracellular enzymatic activity in relation to litter composition, $\mathrm{N}$ deposition, and mass loss. Biogeochemistry 60: 1-24. 
Sinsabaugh, R.L. 2010. Phenol oxidase, peroxidase and organic matter dynamics of soil. Soil Biology and Biogeochemistry 41: 391-404.

Sjostrom, E. 1993. Wood Chemistry. Academic Press, San Diego.

Smith, J.E., L.S. Heath, J.C. Jenkins. 2003. Forest volume-to-biomass models and estimates of mass for live and standing dead trees in U.S. forests. USDA Forest Service: Northeastern Research Station: General Technical Report. NE-298.

Smith, T.G., C.C. Maguire, 2004. Small-mammal relationships with down wood and antelope bitterbrush in Ponderosa pine forests of central Oregon. Forest Science 50: 711-728.

Stevenson, F.J. 1982. Humus chemistry. Genesis, composition, reactions. John Wiley and Sons, New York.

Thomas D.C., D.R. Zak, T.R. Filley. 2012. Chronic N deposition does not apparently alter the biochemical composition of forest floor and soil organic matter. Soil Biology and Biochemistry 54: 7-13.

Thorn R.G., and M.D.J Lynch. 2007. "Fungi and Eukaryotic Algae.” Soil Microbiology and Biochemistry. $3^{\text {rd }}$ edition. Burlington, MA: Academic Press, 2007, pp. 145162.

Treseder, K.K. 2008. $\mathrm{N}$ additions and microbial biomass: a meta-analysis of ecosystem studies. Ecology Letters 11: 1111-1120.

van Diepen, L.T.A., E.A. Lilleskov, K.S. Pregitzer, R.M. Miller. 2007. Decline in arbuscular mycorrhizal fungi in northern hardwood forests exposed to chronic nitrogen additions. New Phytologist 176: 175-183.

Wang, C. X. Fang, P. Guo, G. Han, X. Tian. 2010. Response of degradative enzymes to $\mathrm{N}$ fertilization during litter decomposition in a subtropical forest through a microcosm experiment. Ecology Research 25: 1121-1128. 
Waldrop, M.P., D.R. Zak, R.L. Sinsabaugh. 2004. Microbial community response to nitrogen depositionin northern forest ecosystems. Soil Biology and Biogeochemistry 36: 1443-1451.

Waldrop, M.P. and D.R. Zak. 2006. Response of oxidative enzyme activities to nitrogen deposition affects soil concentrations of dissolved organic carbon. Ecosystems 9: 921-933.

Wallace, Z.P., G.M. Lovett, J.E. Hart, B. Machona. 2007. Effects of nitrogen saturation on tree growth and death in mixed oak forest. Forest Ecology and Management. 243: 210-218.

Weand, M.P., M.A. Arthur, G.M. Lovett, R.L. McCulley, K.C. Weathers. 2010. Effects of tree species and $\mathrm{N}$ additions on forest floor microbial communities and extracellular enzyme activities. Soil Biology and Biochemistry 42: 2161-2173.

Weedon, J.T., W.K. Cornwall, J.H.C. Cornelissen, A.E. Zanne, C. Wirth, D.A. Coomes. 2009. Global meta-analysis of wood decomposition rates: a role for trait variation among tree species? Ecology Letters 12: 45-56.

White, A., G.R. Cannell, A.D. Friend. 2000. The high=latitude terrestrial carbon sink: a model analysis. Global Change Biology 6: 227-245.

Zak, D.R., K.S. Pregitzer, W.E. Holmes, A.J. Burton, G.P. Zogg. 2004. Anthropogenic N deposition and the fate of ${ }^{15} \mathrm{NO}_{3}^{-}$in a northern hardwood ecosystem. Biogeochemistry 69: 143-157.

Zak, D.R., W.E. Holmes, A.J. Burton, K.S. Pregitzer and A.F. Talhelm. 2008. Simulate atmospheric NO3 deposition increases soil organic matter by slowing decomposition. Ecological Applications 18: 2016-2027.

Zak, D.R., K.S. Pregitzer, A.J. Burton, I.P. Edwards. Microbial responses to a changing environment: implications for the future functioning of terrestrial ecosystems. 2011. Fungal Ecology, doi:10.1016/j.funeco.2011.04.001. 
Zeglin, L.H., M. Stursova, R.L. Sinsabaugh, S.L. Collins. 2007. Microbial responses to N addition in three grassland ecosystems. Oecologia 154: 349-359.

Zogg G.P., Zak D.R., Pregitzer K.S. and Burton A.J. 2000. Microbial immobilization and the retention of anthropogenic nitrate in northern hardwood forests. Ecology 81: 1858-1866.

Zollner, P.A., Crane, K.J., 2003. Influence of canopy closure and shrub coverage on travel along coarse woody debris by eastern chipmunks (Tamias striatus). American Midland Naturalist 150, 151-157. 